\title{
Giant worms chez moi! Hammerhead flatworms (Platyhelminthes, Geoplanidae, Bipalium spp., Diversibipalium spp.) in metropolitan France and overseas French territories
}

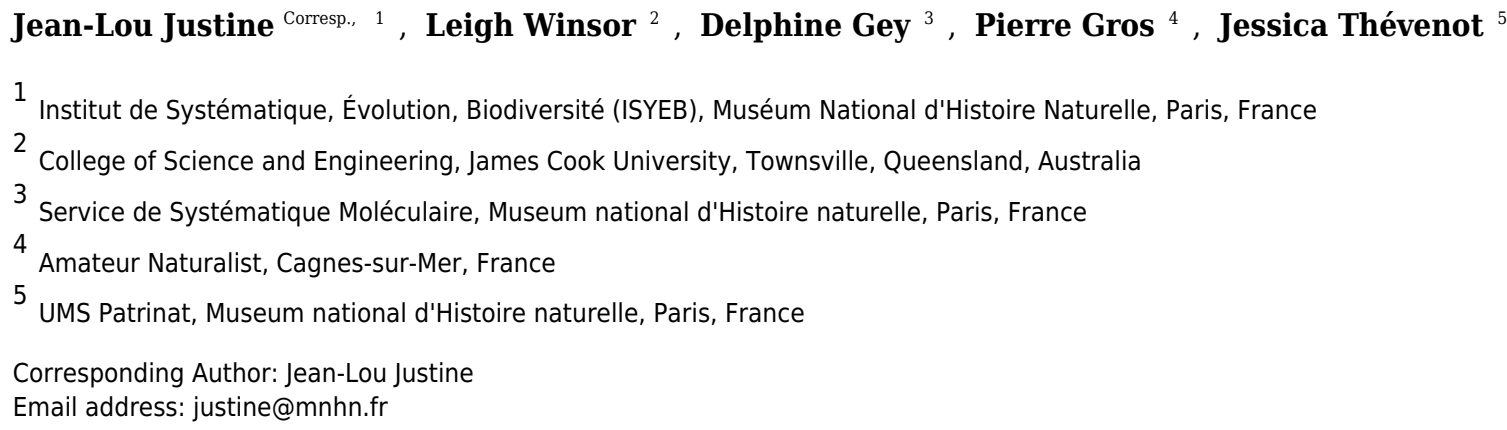

Background. Species of the genera Bipalium and Diversibipalium, or bipaliines, are giants among land planarians (family Geoplanidae), reaching length of $1 \mathrm{~m}$; they are also easily distinguished from other land flatworms by the characteristic hammer shape of their head. Bipaliines, which have their origin in warm parts of Asia, are invasive species, now widespread worldwide. However, the scientific literature is very scarce about the widespread repartition of these species, and their invasion in European countries has not been studied. Methods. In this paper, on the basis of a 4-year survey based on citizen science, which yielded observations from 1999 to 2017 and a total of 111 records, we provide information about the 5 species present in Metropolitan France and French overseas territories. We also investigated the molecular variability of cytochrome-oxidase 1 (COI) sequences of specimens. Results. Three species are reported from Metropolitan France: Bipalium kewense, Diversibipalium multilineatum, and an unnamed Diversibipalium "black" species. We also report the presence of $B$. kewense from overseas territories, such as French Polynesia (Oceania), French Guiana (South America), the Caribbean French islands of Martinique, Guadeloupe, Saint Martin and Saint Barthélemy, and Montserrat (Central America), and La Réunion island (off South-East Africa). For $B$. vagum, observations include French Guiana, Guadeloupe, Martinique, Saint Barthélemy, Saint Martin, Montserrat, La Réunion, and Florida (USA). A probable new species, Diversibipalium sp. "blue", is reported from Mayotte Island (off South-East Africa). Bipalium kewense, $B$. vagum and $D$. multilineatum each showed $0 \%$ variability in their COI sequences, whatever their origin, suggesting that the specimens are clonal, and that sexual reproduction is probably absent. COl barcoding was efficient in identifying species, with differences over $10 \%$ between species; this suggests that barcoding can be used in 
the future for identifying these invasive species. In Metropolitan south-west France, a small area located in the Department of Pyrénées-Atlantiques was found to be a hot-spot of bipaliine biodiversity and abundance for more than 20 years, probably because of the local mild weather. Discussion. The present findings strongly suggest that the species present in Metropolitan France and overseas territories should be considered Invasive Alien Species. Our numerous records in the open in Metropolitan France raise questions: as scientists, we were amazed that these long and brightly coloured worms could escape the attention of scientists and authorities in a European developed country for such a long time; improved awareness about land planarians is certainly necessary. 
1 Giant worms chez moi! Hammerhead flatworms (Platyhelminthes,

2 Geoplanidae, Bipalium spp., Diversibipalium spp.) in metropolitan France and

3 overseas French territories

4

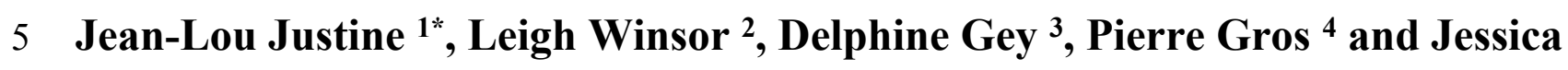

6 Thévenot 5

81 Institut Systématique, Évolution, Biodiversité (ISYEB), Muséum National d'Histoire

9 Naturelle, CNRS, Sorbonne Université, EPHE, 57 rue Cuvier, CP 51, 75005 Paris, France

102 College of Science and Engineering, James Cook University, Townsville, Australia

113 Service de Systématique Moléculaire, Muséum National d'Histoire Naturelle, Paris,

12 France

134 Amateur Naturalist, Cagnes-sur-Mer, France

145 Coordination technique et scientifique de la stratégie nationale relative aux espèces

15 exotiques envahissantes, UMS Patrinat, Muséum National d'Histoire Naturelle, Paris, France

17 Corresponding author: Jean-Lou Justine, justine@mnhn.fr

18 Institut Systématique Évolution Biodiversité (ISYEB),

19 Muséum National d'Histoire Naturelle, CNRS, Sorbonne Université, EPHE,

2057 rue Cuvier, CP 51, 75005 Paris, France 


\section{Abstract}

24 Background. Species of the genera Bipalium and Diversibipalium, or bipaliines, are giants among land planarians (family Geoplanidae), reaching length of $1 \mathrm{~m}$; they are also easily distinguished from other land flatworms by the characteristic hammer shape of their head. Bipaliines, which have their origin in warm parts of Asia, are invasive species, now widespread worldwide. However, the scientific literature is very scarce about the widespread repartition of these species, and their invasion in European countries has not been studied. Methods. In this paper, on the basis of a 4-year survey based on citizen science, which yielded observations from 1999 to 2017 and a total of 111 records, we provide information about the 5 species present in Metropolitan France and French overseas territories. We also investigated the molecular variability of cytochrome-oxidase 1 (COI) sequences of specimens. Results. Three species are reported from Metropolitan France: Bipalium kewense, Diversibipalium multilineatum, and an unnamed Diversibipalium "black" species. We also report the presence of $B$. kewense from overseas territories, such as French Polynesia (Oceania), French Guiana (South America), the Caribbean French islands of Martinique, Guadeloupe, Saint Martin and Saint Barthélemy, and Montserrat (Central America), and La Réunion island (off South-East Africa). For B. vagum, observations include French Guiana, Guadeloupe, Martinique, Saint Barthélemy, Saint Martin, Montserrat, La Réunion, and Florida (USA). A probable new species, Diversibipalium sp. "blue", is reported from Mayotte Island (off South-East Africa). Bipalium kewense, B. vagum and D. multilineatum each showed $0 \%$ variability in their COI sequences, whatever their origin, suggesting that the specimens are clonal, and that sexual reproduction is probably absent. COI barcoding was efficient in identifying species, with differences over $10 \%$ between species; this suggests that barcoding can be used in the future for identifying these invasive species. In Metropolitan south-west France, a small area located in the Department of Pyrénées-Atlantiques was found to be a hot-spot of bipaliine biodiversity and abundance for more than 20 years, probably because of the local mild weather. Discussion. The present findings strongly suggest that the species present in Metropolitan France and overseas territories should be considered Invasive Alien Species. Our numerous records in the open in Metropolitan France raise questions: as scientists, we were amazed that these long and brightly coloured worms could 
52 escape the attention of scientists and authorities in a European developed country for such a long 53 time; improved awareness about land planarians is certainly necessary. 


\section{Introduction}

55 Land planarians (Platyhelminthes, Geoplanidae) are predatory soil-associated animals. Although

56 small species (generally less than $1 \mathrm{~cm}$ in length) such as Microplana spp. or Rhynchodemus spp.

57 are autochthonous in Europe (Álvarez-Presas et al. 2012), large species are not. Reports of

58 invasive alien flatworms in Europe in recent years (Sluys 2016) include Arthurdendyus

59 triangulatus from New Zealand, Platydemus manokwari originally from Papua New Guinea,

60 Obama nungara from Brazil, and Parakontikia ventrolineata, Caenoplana coerulea and

61 Caenoplana bicolor from Australia (see Table 1 for authors of taxa and key references). All

62 these species are conspicuous animals, several centimetres in length. Even larger are the species

63 of Bipalium (and close genera), or "hammerhead flatworms": these can be longer than 20

64 centimetres (von Graff 1899) and one species even attains a length of 1 metre in elongated state

65 (Kawakatsu et al. 1982). In this paper, we focus on these giant species, and we report new

66 findings obtained mainly by citizen science in metropolitan France and overseas French

67 territories in the Caribbean (Guadeloupe, Martinique, and Saint Barthélemy), South America

68 (French Guiana) and Indian Ocean (La Réunion, Mayotte). Five species were found, among

69 which three can be attributed to known binomial taxa (Bipalium kewense, Bipalium vagum and

Diversibipalium multilineatum) and two are unnamed.

Land planarians are dispersed between countries, and within countries, through the 72 transport of plants. Winsor (1983a) summarized knowledge about the world distribution of

73 Bipalium kewense, listing the occurrence of the species in 39 territories; by 2004 the species was

74 recorded in 45 territories (Winsor et al. 2004), and subsequently reported in Northern and

75 Peninsular Italy, Sardinia, and Sicily (Gremigni 2003); Czech Republic and Slovakia (Košel

76 2002); Cuba (Morffe et al. 2016); Ecuador (Wizen 2015); and Pakistan (M. Darley, personal

77 communication to LW). As Sluys (2016) commented: "Almost every year B. kewense is found in new places: for example, this year (2016) it was found on São Miguel Island in the Azores and on São Tomé Island in the Gulf of Guinea". Although such reports from small remote islands are important for our knowledge of these invasive species (and we indeed add many new records of this type in this paper), we consider that the major finding of this paper is that several species of

82 hammerhead flatworms are established in a European country, France, probably for more than 20 
83 years. This highlights an unexpected blind spot of scientists and authorities facing an invasion by 84 conspicuous large invasive animals.

85

86

87

91 Material and methods

\section{Citizen science and collection of information} reproduction. television, and newspapers).

The identification of land planarians from specimens or photographs is sometimes a futile exercise, in the absence of detailed anatomical study. In this paper, we tested identification with sequences of the cytochrome-oxidase 1 (COI). We confirm that barcoding with COI is efficient for the species studied here; in addition, our barcoding study revealed that all specimens in each species showed no genetic variability, suggesting that they are clonal, without sexual

In 2013, one of us (JLJ) organized a citizen science network in France for collecting information about land planarians. This included a blog (http://bit.ly/Plathelminthe) and a twitter account (https://twitter.com/Plathelminthe4). These efforts were advertised through the media (radio,

Reports of sighting of land planarians were received from citizens, mainly by email, sometimes by telephone. Photographs and details about locality were solicited, and only reports including this information were considered. Wrong records (slugs, myriapods, earthworms, leeches, caterpillars, nematomorphs, and nemerteans) were eliminated. Information collected from citizen science allowed monitoring of several land planarians (Justine et al. 2014a). Photographs were studied, and species were identified whenever possible. Only information relative to bipaliines is reported in this paper. Sometimes citizens provided records dating from before the survey, such as an amateur movie taken in 1999. Most citizens provided an authorisation to use the photographs at the time of the initial contact by email. When we prepared this paper for publication, we sought authorization to use the photographs and to publish them under a Creative Commons Licence; only one of the citizens refused to provide the authorization, but some of them did not respond, probably simply because they changed their emails or did not check them. 
109 In these cases, we provide the scientific information about the presence of species, but we do not

110 include the photograph of the worm or the name of the citizen in the paper.

111 Although these efforts were originally aimed at collecting information from Metropolitan France,

112 they unexpectedly reached French territories in other continents and provided additional

113 information and specimens.

\section{Collection of specimens}

115 In some cases, after examination of photographs, specimens were solicited from citizens who

116 reported sightings; they were sent either alive or in ethanol by the citizens, registered in the

117 collections of the Muséum National d'Histoire Naturelle, Paris (MNHN), and processed for

118 molecular analysis.

119 When specimens were obtained alive, they were fixed in hot water then preserved in $95 \%$

120 ethanol. In some cases, some specimens were also fixed in hot water and preserved in $4 \%$

121 formaldehyde solution.

122 The species descriptions are based upon specimens and photographs obtained in this project.

123 Molecular sequences

124 For molecular analysis, a small piece of the body $\left(1-3 \mathrm{~mm}^{3}\right)$ was taken from the lateral edge of

125 ethanol-fixed individuals. Genomic DNA was extracted using the QIAamp DNA Mini Kit

126 (Qiagen). Two sets of primers were used to amplify the COI gene. A fragment of $424 \mathrm{bp}$

127 (designated in this text as "short sequence") was amplified with the primers JB3 (=COI-ASmit1)

128 (forward 5'-TTTTTTGGGCATCCTGAGGTTTAT-3') and JB4.5 (=COI-ASmit2) (reverse 5'-

129 TAAAGAAAGAACATAATGAAAATG-3') (Bowles et al. 1995; Littlewood et al. 1997). The

130 PCR reaction was performed in $20 \mu \mathrm{l}$, containing $1 \mathrm{ng}$ of DNA, $1 \times$ CoralLoad PCR buffer, $3 \mathrm{Mm}$

$131 \mathrm{MgCl} 2,66 \mu \mathrm{M}$ of each $\mathrm{dNTP}, 0.15 \mu \mathrm{M}$ of each primer, and 0.5 units of Taq DNA polymerase

132 (Qiagen). The amplification protocol was: 4' at $94^{\circ} \mathrm{C}$, followed by 40 cycles of $94^{\circ} \mathrm{C}$ for 30 ',

$13348^{\circ} \mathrm{C}$ for $40^{\prime},, 72^{\circ} \mathrm{C}$ for $50^{\prime}$, with a final extension at $72^{\circ} \mathrm{C}$ for 7 '. A fragment of 825 bp was

134 amplified with the primers BarS (forward 5'-GTTATGCCTGTAATGATTG-3') (Álvarez-Presas

135 et al. 2011) and COIR (reverse 5'-CCWGTYARMCCHCCWAYAGTAAA-3') (Lázaro et al.

136 2009), following (Mateos et al. 2013). PCR products were purified and sequenced in both 
137 directions on a 3730xl DNA Analyzer 96-capillary sequencer (Applied Biosystems). Results of

138 both analyses were concatenated to obtain a COI sequence of $909 \mathrm{bp}$ in length (designated in this

139 text as "long sequence"). Sequences were edited using CodonCode Aligner software

140 (CodonCode Corporation, Dedham, MA, USA), compared to the GenBank database content

141 using BLAST and deposited in GenBank under accession number MG655587- MG655618. For

142 several specimens only "short" sequences were obtained (Table 2).

\section{Trees and distances}

144 MEGA7 (Kumar et al. 2016) was used to estimate genetic distances (kimura-2 parameter 145 distance) and the evolutionary history was inferred from the kimura-2 parameter distance using 146 the Neighbour-Joining method (Saitou \& Nei 1987); all codon positions were used, with 1000 147 bootstrap replications. The evolutionary history was also inferred using Maximum Likelihood 148 (ML) method. The best evolutionary model for the data set was estimated in MEGA7 (Kumar et 149 al. 2016) under the Bayesian Information Criterion (BIC) to be Hasegawa-Kishino-Yano model 150 (Hasegawa, Kishino \& Yano, 1985) with a discrete Gamma distribution and some sites

151 invariables $(\mathrm{HKY}+\mathrm{G}+\mathrm{I})$. The ML tree was computed in MEGA7, with 100 bootstrap 152 replications.

\section{A note about taxonomy of Diversibipalium}

154 Morphology-based taxonomy of land planarians is based on a suite of characters, especially 155 those afforded by internal anatomy, and in particular those of the reproductive system (Winsor et 156 al. 1998). Reproductive organs are only available in sexually mature specimens and require 157 extensive histological preparations for their description. Unfortunately, many species of land 158 planarians have been described from external morphology only. Some species only reproduce 159 asexually (scissiparity) and thus do no show mature organs; this is especially the case of some 160 invasive species when they are not in their region of origin. However, the bipaliines represent a 161 special case because the external morphology, i.e. the presence of a "hammer" head is distinctive 162 of the subfamily, which thus can be easily differentiated if a photograph of the head is available.

163 The genus Diversibipalium Kawakatsu et al., 2002 is a collective group created to temporarily 164 accommodate species of the subfamily Bipaliinae whose anatomy of the copulatory apparatus is 165 still unknown (Kawakatsu et al. 2002). For this reason, we attribute our two undescribed species, 
166 "black" and "blue" to this genus. We insist that attribution of species to the genus

167 Diversibipalium does not mean that these species have characters in common - the only feature

168 they share is our ignorance of their internal anatomy. These two species will be histologically

169 examined and fully described by the authors elsewhere.

\section{Results}

\section{Collection of information from citizen science}

172 After the initial finding in June 2013 of two species of land planarians in his garden by Pierre 173 Gros, an amateur entomologist and photographer, more than 600 reports were received over 4 174 years (June 2013-September 2017). Most records were from citizens, some from scientists or 175 other professionals. Unexpectedly, these reports included mentions of more than 8 species of land planarians (Justine et al. 2014a), the most recent being Marionfyfea adventor. Among these, 111 reports concerned bipaliines. Figure 1 is a map of these records in Metropolitan France.

178 Results are presented here as follows: after an assessment of the identification of specimens from

179 both morphology and molecules, separate paragraphs provide, for each species, a brief

180 description and its range in Metropolitan France and overseas French territories, from both 181 sampled specimens and photographs obtained through citizen science.

\section{Molecular identification of sampled specimens}

183 Sequences were obtained from specimens belonging to five species (Table 2), including three 184 named species, Bipalium kewense (specimens from 13 localities, 17 sequences including 185 replicates), Diversibipalium multilineatum (specimens from 4 localities, 8 sequences including 186 replicates), Bipalium vagum (specimens from 3 localities, 5 sequences including replicates) and 187 two unnamed species, Diversibipalium "black" (1 specimen from 1 locality, 1 sequence) and 188 Diversibipalium "blue" (specimens from 2 localities, 6 sequences including replicates).

189 A tree (Figure 2) was constructed from an analysis of our new COI sequences and sequences 190 from GenBank. Both NJ and ML trees showed comparable topologies, but the bootstrap values 191 of branches, in both trees, were contrasted: $100 \%$ for all branches representing species, and very 
192 low for upper nodes. We thus considered that the trees were informative for showing the genetic

193 identity of all specimens within a species, but not for inferring relationships between taxa. Thus,

194 no further comment about interspecies relationships are given in the rest of this text; in that we

195 follow the general principles of COI barcoding (Hebert \& Gregory 2005): "we emphasize that

196 DNA barcodes do not aim to recover phylogenetic relationships; they seek instead to identify

197 known species and to aid the discovery of new ones". We remarked, but do not comment,

198 probable misidentification of certain sequences deposited in GenBank, such as Novibipalium

199 venosum or the "D. multilineatum” HM346600.

200 Each of the three named species belonged to a clade with high (100\%) bootstrap support (Figure 201 2).

202 For Bipalium kewense, the clade includes GenBank sequences from Spain, Azores Islands, and

203 Cuba; our 13 new sequences (excluding replicates) are from 7 localities in metropolitan France,

2043 overseas French territories (Guadeloupe, Martinique, French Guiana) and 2 other countries,

205 Monaco and Portugal. All COI sequences were strictly identical.

206 For Diversibipalium multilineatum, the clade includes GenBank sequences from Italy and France

207 (sequence from specimen MNHN JL177, already published by Mazza et al., 2016), and our 6

208 new sequences (excluding replicates) are from 3 localities in metropolitan France. All COI

209 sequences were strictly identical.

210 For Bipalium vagum, no sequence was found in GenBank. Our 5 new sequences are from 1

211 overseas French territory (Guadeloupe) and 2 other countries, Montserrat (West Indies) and

212 Florida, USA. All COI sequences were strictly identical.

213 For Diversibipalium "black" from Metropolitan France and Diversibipalium "blue" from

214 Mayotte, each sequence was found to have no close match in GenBank sequences or our new

215 sequences, suggesting that they each belong to a species which has never been sequenced for

216 COI gene. 


\section{Distances between taxa}

218 "Short" sequences were obtained from all specimens and "long" sequences" were obtained from 219 only some of them. Distances between species of bipaliines were computed from two sets of 220 sequences, "short" sequences and "long" sequences.

221 The first set included "short" sequences and 7 bipaliine taxa were available. Distances varied 222 from $10.9 \%$ to $21.2 \%$ (Table 3). The closest taxa were B. kewense - D. multilineatum with an 223 interspecific distance of 10.9\%, and the most distant were Diversibipalium "blue" and B.

224 adventitium with $21.2 \%$.

225 The second set included only "long" sequences and 4 bipaliine taxa were available. Distances 226 were higher than with short sequences and varied from $15.9 \%$ to $25.9 \%$ (Table 4). The closest 227 taxa were, again, B. kewense - D. multilineatum with an interspecific distance of $15.9 \%$, and the 228 most distant were Diversibipalium "blue" and D. multilineatum with $25.9 \%$.

\section{Morphology, taxonomy and distribution}

230 Bipalium kewense Moseley, 1878

\section{Morphology and colour pattern (Figures 3-9)}

232 Living specimens are long and thin and ranged in length from $100 \mathrm{~mm}-270 \mathrm{~mm}$ (Table 5).

233 Preserved specimens from which COI results were obtained, measured $170 \mathrm{~mm}$ (MNHN JL224),

$234120 \mathrm{~mm}$ (MNHN JL308) and $65 \mathrm{~mm}$ (MNHN JL270) in length, with the relative mouth: body

235 length $41.2 \%, 41.7 \%$ and $32.3 \%$ respectively. None of the preserved specimens examined had a 236 gonopore and thus they were considered to be non-sexual. The anterior end is expanded into a 237 transversely semi-lunate-shaped headplate with recurved lappets (falciform). The dorsal ground 238 colour is usually a light - mid ochre (Figure 3), with five black to grey-coloured longitudinal 239 stripes: a median, paired lateral, and paired marginal stripes which begin at or near the base of 240 the headplate where it joins the body the "neck". The dorsal headplate (Figure $\mathbf{4 , 5}$ ) is usually 241 the same colour as the body, or slightly darker, with recurved posterior margins. The median 242 stripe is black, narrow, with sharp margins, extending caudally from below the neck over the 
243 entire body length, and is broadest over the pharyngeal area. Paired dark to pale brown coloured

244 lateral stripes with diffuse margins, constant over the entire body length, are separated from the

245 median and marginal stripes by an equal width of ground colour. The paired black, fine, marginal

246 stripes, with sharp margins, extend the entire body length. The paired lateral and marginal stripes

247 unite just behind the neck to form an incomplete black transverse neck band, interrupted dorsally

248 by a small median gap, and ventrally by the creeping sole. The ventral headplate is a greyish

249 colour with a light ochre margin. The ventral surface (Figure 6) is a light ochre colour, with a

250 distinct off-white creeping sole, delineated by paired, narrow, longitudinal diffuse grey-violet

251 stripes beginning at the ventral termination of the collar, and extending the entire body length. In

252 Figure 7, we present evidence of predation on an unidentified native European earthworm, and

253 in Figures 8-9 evidence of reproduction by scissiparity where the shed fragment is immediately

254 motile but does not possess the characteristic hammer-shaped head.

\section{Discussion and differentiation from other species}

256 The specimens of $B$. kewense which were sent to us, or for which we received only photographs

257 corresponded to published morphological descriptions of the species (Winsor 1983a). Bipalium

258 kewense is differentiated externally from similar striped species by the incomplete black

259 transverse band at the neck (the "collar"), the thin dorsal median longitudinal stripe that begins at

260 or below the transverse neck band, the pattern and form of the dorsal and ventral stripes, and the

261 relative position of body apertures (Winsor 1983a).

\section{Records obtained from citizen science}

263 We obtained 50 records of $B$. kewense, including 14 confirmed by molecules (Table 2) and 36

264 from photographs only (Table 6). Localities where bipaliines were found in the open, generally

265 in gardens, include Portugal (1 record), Martinique (3), Guadeloupe (6), French Guiana (1),

266 French Polynesia (1), La Réunion (1), Monaco (1), i.e. from 7 territories in 5 continents (Europe,

267 North America, South America, Africa, Oceania), and 36 from Metropolitan France (Figure 1),

268 from 9 departments: Corse-Sud (Corsica) (2), Var (2), Gironde (1), Loire-Atlantique (1), Landes

269 (3), Alpes-Maritimes (5), Yonne (2), Hautes-Pyrénées (1) and Pyrénées-Atlantiques (16). In

270 addition, we received two reports in hothouses in the Department of Yonne. Among the 34 
271 records in the open in Metropolitan France, 16, i.e. more than half, were from the department of

272 Pyrénées-Atlantiques (Tables 2, 6). The distribution of our records is shown in Figure 1 for

273 Metropolitan France (including Corsica). Dates of records ranged 1999-2017; the oldest record

274 (1999) was in the Pyrénées-Atlantiques.

\section{Molecular results}

276 The COI sequences were strictly identical for specimens from all localities where specimens 277 were sequenced.

\section{Diversibipalium multilineatum (Makino and Shirasawa, 1982)}

\section{Morphology and colour pattern (Figures 10-14)}

280

281

282

283

284

285

286

287

288

289

290

291

292

293

294

295

296

297

Living specimens ranged in length from $150 \mathrm{~mm}$ (MNHN JL 177) to $210 \mathrm{~mm}$ (MNHN JL059). Representative preserved specimens from which COI results were obtained measured $85 \mathrm{~mm}$ (MNHN JL210), 65 mm (MNHN JL161A), and 60 mm (MNHN JL142A) in length (Table 5), with the relative mouth: body length $29.4 \%, 38.5 \%$, and $41.7 \%$ respectively. None of the specimens examined had a gonopore and thus they were considered to be non-sexual. The body is elongated (Figure 10) with the anterior end expanded into a transversely semi-lunate-shaped headplate with rounded lappets (Figure 11-13). Immediately behind the neck the body narrows to form a "neck", then gradually broadens to the maximum width over the pharyngeal region, and tapers slightly to a rounded posterior end. The dorsal ground colour including the headplate is usually a light brown-ochre with five evenly spaced, black to dark brown longitudinal stripes: a median, paired lateral, and paired marginal longitudinal stripes. The median stripe is black, and narrow with sharp margins. It has a pronounced characteristic lenticulate shape beginning at the anterior third of the headplate, then tapering to a thin dark stripe extending caudally along the entire body length, broadest over the pharyngeal area. Either side of the median stripe, each separated by an equal width of ground colour is a lateral stripe and submarginal stripe both of which join at the neck in the inner curvature of the headplate at the "neck" and extend the entire body length. The lateral stripes are a black to dark brown colour with diffuse margins, approximately 2-3 times the width of the median stripe; the narrow, brown paired marginal 
298 stripes are approximately the same thickness as the median stripe. The ventral surface (Figure

299 14) is a light brown ochre colour, generally slightly paler than that dorsally, with a distinct white

300 creeping sole, delineated by paired, narrow, longitudinal brown stripes beginning at the ventral

301 termination of the collar, and extending the entire body length. A finer, generally discontinuous

302 mid ventral dark stripe extends from the base of the headplate to the posterior end.

303 Discussion and differentiation from other species

304 The specimens of $D$. multilineatum which were sent to us, or for which we received only

305 photographs corresponded to the published morphological description of the species (Makino \&

306 Shirasawa 1983; Mazza et al. 2016). Diversibipalium multilineatum is differentiated externally

307 from similar striped species by the presence of the lenticulate-shaped beginning of the median

308 stripe on the headplate, presence of distinct dark paired ventral median stripes, the thin, dark,

309 generally incomplete midventral longitudinal stripe, and the relative position of the mouth.

\section{Records obtained from citizen science}

311 We obtained a total of 19 records. One record was from Switzerland and 16 from outdoor

312 locations in Metropolitan France, in the departments of Ariège (1), Haute-Garonne (3), Isère (2),

313 Landes (2), Val d'Oise (2), and Pyrénées-Atlantiques (6); one record was confirmed two years in

314 a row (2014-2015) in the same garden in Bellocq (Pyrénées-Atlantiques). In addition, two

315 records were from hot-houses, in the Department of Lot (1) and Val d'Oise (1). Among the 16

316 records in the open in Metropolitan France, more than one third (6) are from the department of

317 Pyrénées-Atlantiques. The distribution of our records is shown in Figure 5 for Metropolitan

318 France (including Corsica). Dates of records ranged 2010-2017; the oldest record (2010) was in

319 the Pyrénées-Atlantiques (Tables 2, 7).

320 Molecular results

321 As for $B$. kewense, the COI sequences of $D$. multilineatum were strictly identical for specimens

322 from all localities. 
323 Bipalium vagum Jones and Sterrer, 2005

324 Morphology and colour pattern (Figures 15-18)

325 Living specimens are medium sized, with one measuring around $36 \mathrm{~mm}$ (Table 5, observation

326 V04, from a scaled photo). Preserved specimens, from which COI results were obtained,

327 measured $27.5 \mathrm{~mm}$ (MNHN JL164), $25.6 \mathrm{~mm}$ (MNHN JL163) and $15 \mathrm{~mm}$ (MNHN JL307) in

328 length, with the relative mouth: body length $60.7 \%, 50.4 \%$ and $49 \%$ respectively, and gonopore:

329 body length 70.7\% (MNHN JL163) and 72\% (MNHN JL307).

330 Dorsal ground colour is a pale brown, with three black to brown dorsal longitudinal stripes: a

331 median sharply demarcated broad black stripe, and two lateral dark brown stripes, less sharply

332 delineated, all beginning at the transverse neck band, continuing the length of the full body, and

333 often terminating in a well-defined black tip. The longitudinal stripes are separated from each

334 other by an equal width of ground colour (Figures 15-18).

335 Discussion and differentiation from other species

336 The specimens of $B$. vagum which were sent to us, or for which we received only photographs

337 corresponded to the published morphological description of the species (Jones \& Sterrer 2005).

338 Bipalium vagum is distinguished externally from species of similar morphology by the

339 combination of characters, especially its relatively small size, the transverse neck band that is

340 continuous dorsally, from which the broad median black stripe originates, and the relative

341 position of the body apertures.

\section{Records obtained from citizen science}

343 No record was obtained from Metropolitan France. We obtained 39 records (Tables 2, 8), all in

344 the open, from French Guiana (4 records) and from 5 islands in the West Indies, including

345 Montserrat (1) and 4 French territories, namely Guadeloupe (10), Martinique (3), Saint

346 Barthélemy (2), and Saint Martin (1), and, from the Indian Ocean island of La Réunion (15);

347 specimens from Florida, USA, were also sequenced. Unfortunately, in spite of the many

348 photographic records from La Réunion, no specimen was received for sequencing, but the 
349 morphology and colour pattern were similar to other localities (Figures 15-18). Dates of records

350 ranged 2005-2017; the oldest record (2005) was from French Guiana (Tables 2, 7).

351 Molecular results

352 The COI sequences were strictly identical for specimens from all localities.

353 Diversibipalium sp. "black" from Metropolitan France

354 Morphology and colour pattern (Figures 19-21)

355 The living specimen attains a length of $20-25 \mathrm{~mm}$. A preserved sexual specimen (MNHN

356 JL090) is $20 \mathrm{~mm}$ long and $3.2 \mathrm{~mm}$ wide, with the mouth situated ventrally $6 \mathrm{~mm}$ (mouth: body

357 length $30 \%$ ), and gonopore $7.8 \mathrm{~mm}$ (gonopore: body length 9\%) from the anterior end.

358 The dorsal ground colour of this small planarian is black, with no evidence of dorsal stripes

359 (Figures 19-21). The ventral surface is a light grey colour with paler creeping sole.

360 Differentiation from other species

361 In the absence of detailed data in the literature, it is difficult at present to determine whether

362 Diversibipalium sp. 1 "black" is a new species, or one of the small black species of

363 Diversibipalium such as Diversibipalium sp. "Kuanmoto" of Kawakatsu et al. (2005).

364 Possible origin of this species

365 We do not propose any hypothesis concerning the geographic origin of this species, apart the fact

366 that it is obviously not European, since no bipaliines are known from this continent.

\section{Molecular results}

368 The COI barcode of this specimen is clearly different from all other known sequences. We can

369 safely claim that this species has never been sequenced before. Whether the species is already

370 described or not is not an easy question to answer, and would require examination of mature

371 specimens. 


\section{Diversibipalium sp. "blue" from Mayotte (Indian Ocean)}

373 Morphology and colour pattern (Figures 22-26)

374 Unfortunately, scaled photos of this planarian are unavailable and the length of the living

375 specimen could not be determined. The preserved sexual specimen is $9 \mathrm{~mm}$ long and $1 \mathrm{~mm}$ wide,

376 with the mouth situated ventrally approximately $3.5 \mathrm{~mm}$ (mouth: body length $39 \%$ ), and

377 gonopore $6.5 \mathrm{~mm}$ (gonopore: body length $72.2 \%$ ) from the anterior end.

378 The headplate in this beautiful, small planarian is a rusty-brown colour that extends to some

379 irregular patches on the "neck". The dorsal ground colour is an iridescent blue-green ("dark

380 turquoise glitter"), and the ventral surface a very pale brown colour, with the creeping sole white

381 to pale green. The iridescence and blue-green colour are lost on fixation, leaving a dark brown

382 ground colour (Figures 22-26).

383 Differentiation from other species

384 There are no other reports of a bipaliine planarian with this morphology.

385 Possible origin of this species

386 Mayotte and the Comoros are small volcanic islands which experienced intense human trade

387 from centuries with the close island and Madagascar and more distant territories including Asia.

388 Any of these could be the origin of this species.

389 Records obtained from citizen science

390 We obtained records of this species only from Mayotte, from two independent observers, one

391 who provided specimens and photographs and one who provided only photographs (Tables 2, 9).

392 Molecular results

393 The COI barcode of this specimen is clearly different from all other known sequences. We can

394 safely claim that this species has never been sequenced before. Whether the species is already

395 described or not is not an easy question to answer. 
396 Discussion

397 Validity of COI for barcoding of bipaliine flatworms

398 Barcoding based on sequences of the mitochondrial gene cytochrome c oxidase I (COI) has been 399 proposed as a solution to the problem of species identification (Hebert et al. 2003). COI-based 400 barcodes have been found to be effective in various groups, including butterflies (Lepidoptera)

401 (Hebert et al. 2003) or fish (Ward et al. 2005). In flatworms (Platyhelminthes), although barcode 402 based only on COI sequences might not be the best choice for some groups (Vanhove et al.

403 2013), recent studies showed that it efficiently differentiates species in groups such as 404 monogeneans (Ayadi et al. 2017; Chaabane et al. 2016) and various triclads (Álvarez-Presas \& 405 Riutort 2014) including land planarians (family Geoplanidae) (Álvarez-Presas et al. 2011;

406 Álvarez-Presas et al. 2014; Álvarez-Presas et al. 2012).

407 The present study shows that COI short sequences, easily obtained from almost all specimens, 408 have inter-specific distances of 10.9-21.2\% (Table 3). These interspecific distances are high 409 enough to differentiate species of bipaliines, especially in the absence of intra-species variation.

410 Long sequences provide even higher inter-specific distances, ranging 15.9-25.9\% (Table 4) but

411 these are less easily obtained, and the database includes only four species. Of course, it might be 412 objected that the current database ( 7 species with short sequences) is extremely limited in 413 comparison to the number of species described in the bipaliines - more than 160 (Winsor 1983a).

414 However, the current database includes most invasive world-wide species, inter-specific

415 distances are high, and intra-specific variation was almost inexistent for most species. For these 416 reasons, we believe that identification of common invasive species of bipaliine flatworms can 417 reliably be done from COI barcoding. Barcoding can be done from a very small worm, 418 immature, or even a fragment. Moreover, COI barcoding can probably alert scientists to the 419 presence of species not previously sequenced, if a sequence different from those reported in the 420 present study is found.

421 The fact that some bipaliines do not reproduce sexually outside their native habitat or tropical 422 and subtropical climates, but only by scissiparity (Winsor 1983a), is probably one reason 423 explaining why no variability was found in specimens, since specimens are clones, and no or 424 very few mutations can happen. However, this explanation is not sufficient, since several 
425 populations from various origins, each cloning itself, could be present in the world. In contrast, 426 for Platydemus manokwari, COI sequences demonstrated the existence of at least two haplotypes 427 in the world, probably corresponding to two populations and different ways of invasion of the 428 world (Justine et al. 2015). Our current data on bipaliines suggest that one population is at the 429 origin of the invasion for each species. This is particularly striking for $B$. kewense, with identical 430 molecular records from several continents.

Persistence of Bipalium kewense and Diversibipalium multilineatum in the open in Metropolitan France

433 434

435

436

437

438

439

440

441

442 443

444

445

446

447

448

449

450

451

452

453

Bipalium kewense was originally described from specimens in one of the hot-houses in Kew, United Kingdom (Moseley 1878). Originally from Vietnam to Kampuchea, the species is currently cosmopolitan (Winsor 1983a). However, distinctions are important between a species which is found only in protected and restricted constructions such as hot-houses, and species which can freely live and reproduce in the open. Clearly, B. kewense is an invasive species in the open in countries with tropical moist or humid semitropical climates and appears to be restricted to anthropogenically-modified habitats; this is the case in the Caribbean, such as Guadeloupe or Martinique from where we obtained specimens. However, until recently (Justine et al. 2014b), it was considered that $B$. kewense, in Europe, was only confined to hot-houses and thus not an invasive species. Examination of literature and citizen-science information (Figure 1) now proves otherwise.

In France, the outdoors occurrence of B. kewense was reported in Orthez and Bayonne in 2005 (Vivant 2005). Through citizen science, we obtained a movie of the worm filmed in the nearby locality of Urcuit in 1999. Moreover, we obtained information about the presence of the species in Arthez de Béarn, Hasparren, Villefranque, Urt (all in 2014), near Jurançon (2016), Nay (2016) and Saint Jean de Luz (2016), Billère and Ustaritz (2017) and, as in the report by Vivant, in Bayonne and Orthez again (2014). We have obtained specimens from Saint-Pée-sur-Nivelle (2013), Ustaritz (2014), Bassussary (2014) and Orthez (2014). All these localities are in the Department of Pyrenées-Atlantiques, and we also have three records from the Department of Landes, north of Pyrenées-Atlantiques, along the Atlantic coast including Mimbastes (2014, with molecular information), Hagetmau (2008) and Biscarosse (2014) and one record from the 
454 Department of Hautes-Pyrénées, farther from the coast, in Peyrouse (2017) (Tables 2, 6). The 455 remark by Vivant that the animal was collected "five times in the last 20 years", the record from 456 1999, and the recent record and specimens in the same locality (Orthez) in 2014 strongly 457 suggests that the species is now established in the open in Orthez and in several localities of the 458 Department of Pyrenées-Atlantiques (Figure 27). An alternative hypothesis would be that a 459 single plant nursery near Bayonne acts as a continuing reservoir of planarians and that all these 460 records are in fact specimens that escaped from recently bought plants, but which subsequently 461 died after being released in the open; this hypothesis is falsified by records over several years in 462 similar localities. Recently, one citizen in Billère (Pyrénées-Atlantiques) sent us repeated records 463 in the same garden in September and December 2017 and January 2018, clearly showing 464 numerous specimens alive outdoor, even in winter; they were found at various depths under the 465 soil surface in January, clearly a way for the species to survive the cold season.

466 We note that all our records are from gardens and that none were from places away from human 467 presence; this can be expected from citizen science data.

468 We briefly comment the climate of this region. The department of Pyrenées-Atlantiques is the 469 most southern department on the Atlantic coast of France; it includes a mountainous region and a 470 low altitude region along the ocean. The latter has an Atlantic climate. Within the department, 471 we note that most records (Nay, Urcuit, Urt, Saint-Jean-de-Luz, Saint-Pée-sur-Nivelle, Ustaritz, 472 and Bassussary) are from a small area around Bayonne, along the Atlantic coast (Figure 27). 473 The major limiting factor for a tropical species in Europe is, of course, low temperature. For a 474 land planarian which is sensitive to drought and freezing, the numbers of days of drought in 475 summer and the number of days of freezing temperature in winter are also important limiting 476 factors. Detailed meteorological records are available for Biarritz, a locality close to Bayonne 477 (Infoclimat 2017): annual mean temperature is $13.7^{\circ} \mathrm{C}$, annual rain is $1483 \mathrm{~mm}$, even the dryer 478 months (July and August) show a mean of 9-10 days with rain, and the number of days with 479 temperature lower than $-5^{\circ} \mathrm{C}$ is only 1.5 /year. This suggests that this region is particularly 480 suitable for land planarians. Other localities in the south of France, such as Departments of Var 481 and Alpes-Maritimes, and Corsica, both in Mediterranean climate, have higher temperatures and 482 thus could be more suitable for tropical species, but they have longer periods of drought in 483 summer (Infoclimat 2017). 
484 Interestingly, one record of Diversibipalium multilineatum is also from the same department, in 485 Bellocq (with records on two years), and the single record of Diversibipalium sp. "black" is also 486 from the same department, in Saint-Pée-sur-Nivelle, in a garden where B. kewense is also 487 present. Other invasive land planarians found in the Pyrenées-Atlantiques include Obama 488 nungara, Caenoplana bicolor and Parakontikia ventrolineata (data from citizen science). With a 489 total of six species of invasive flatworm, clearly the Pyrenées-Atlantiques department is a hot 490 spot of diversity and a small paradise for invasive land planarians.

491 For Diversibipalium multilineatum, we have also two records in the same gardens in two 492 consecutive years (Table 7). This suggests that this species also is established in the open in 493 Metropolitan France, but the total number of records is lower (16 vs 34 for B. kewense). One of 494 the records was of hundreds of animals.

495 A more detailed assessment of the ecoclimatic and other data for the distribution of invasive land 496 planarians in France and French Territories is beyond the scope of this paper.

497 Do bipaliine land planarians qualify as invasive species in Metropolitan 498 France?

499 We received several reports by citizens mentioning dozens of specimens in their gardens 500 (Supplemental Files 1 \& 2); in some cases, citizens repeatedly reported high numbers, even 501 when worms were removed by hand and destroyed. Such reports justify the species as "invasive" 502 in the common, public sense of the word.

503 However, the term "invasive species" has a more precise meaning in science. Invasive Alien 504 Species (IAS) are defined by both the Convention on Biological Diversity and the International 505 Union for Conservation of Nature as "species whose introduction and/or spread outside their 506 natural past or present distribution threatens biological diversity" (Convention on Biological 507 Diversity ; International Union for Conservation of Nature). Legal definitions are also available 508 in various countries. For the USA, Executive Order 13112 (1999) (Executive Order 13112 1999) 509 defines an invasive species as "an alien species whose introduction does or is likely to cause 510 economic or environmental harm or harm to human health.” In Europe, the Institute for 511 European Environmental Policy (Kettunen et al. 2009) uses the following definition: "Invasive 
512 alien species (IAS) are non-native species whose introduction and/or spread outside their natural

513 past or present ranges poses a threat to biodiversity". The most recent legal text (European

514 Parliament 2014) reads (a few parts are deleted here for simplification): "(1) The appearance of

515 alien species, whether of animals, plants, fungi or micro-organisms, in new locations is not

516 always a cause for concern. However, a significant subset of alien species can become invasive

517 and have serious adverse impact on biodiversity and related ecosystem services, as well as have

518 other social and economic impact, which should be prevented. [...] (2) Invasive alien species

519 represent one of the main threats to biodiversity and related ecosystem services. [...](3) The

520 threat to biodiversity and related ecosystem services that invasive alien species pose takes

521 different forms, including severe impacts on native species and the structure and functioning of

522 ecosystems through the alteration of habitats, predation, competition, the transmission of

523 diseases, the replacement of native species throughout a significant proportion of range and

524 through genetic effects by hybridisation."

525 According to these definitions, bipaliines found in gardens in Metropolitan France and other

526 localities mentioned in this paper should clearly be considered as Invasive Alien Species,

527 because bipaliines are predators, and as such threaten the soil fauna. In absence of detailed

528 ecological studies, we cannot estimate the exact impact of these worms on the fauna; the very

529 large size of bipaliine flatworms, making them the largest terrestrial invertebrate predators,

530 suggests that this impact is not negligible (Zaborski 2002).

531 A precise classification of alien species based on their environmental impacts has recently been 532 proposed (Blackburn et al. 2014); bipaliines fulfil three of the criteria listed in Table 1 of

533 Blackburn et al. 2014: competition, predation, and poisoning/toxicity. The first two criteria are

534 fulfilled by the predatory character of bipaliines, especially on larger prey (Ducey et al. 1999;

535 Johri 1952; Zaborski 2002); the presence of tetrodotoxin (Stokes et al. 2014) fulfils the criterion

536 of toxicity, and this is reinforced by reports of animals vomiting ingested bipaliines (Winsor

537 1983b). However, in absence of ecological studies, bipaliines should currently be classified as

538 “data deficient” (Box 1 in Blackburn et al. 2014).

539 In conclusion, bipaliines are Invasive Alien Species in Europe and the French overseas territories

540 mentioned in this paper (Figure 28), but an exact evaluation of their ecological impact requires

541 ecological studies, which are outside the scope of this paper. 


\section{How could 40-cm long invasive worms escape the attention of the}

\section{3 scientists for 20 years?}

544 At the beginning of our study, we were intrigued by the almost total absence of published

545 information about the presence of bipaliines in France. The record by Vivant (2005) was the only

546 one we could find, and since it was published in a rather obscure mycological journal, it certainly

547 did not receive national nor international attention. Moreover, we are still amazed by the

548 complete lack of response from scientific authorities at the presence of these worms. One of the

549 early records we received (2013) was from a kindergarten in which the children were reportedly

550 scared by hundreds of "small snakes" on the grass (these were later identified as $D$.

551 multilineatum). We also received a report of a citizen who showed a long hammerhead worm

552 found on the fur of her cat to its veterinarian and was told it was a tapeworm (cestode). Other

553 citizens explained that they tried to obtain identifications of land planarians from local

554 universities and were told that the worms were leeches, and/or plain, uninteresting animals.

555 Invasive land planarians were not known in France 10 years ago (Justine et al. 2014a) and the

556 professionals involved in these anecdotes probably were never taught about them. Clearly, more

557 education is needed about land planarians, which, in Europe, will be more and more often

558 encountered by citizens and professionals in agriculture, landscaping, veterinary science and

559 medicine.

560 It is also amazing that the presence of such conspicuous animals never provoked a response from

561 scientific authorities, although reports of tiny insect invasives often are followed by appropriate

562 measures; again, the ignorance of professional scientists, science technicians, and amateur

563 naturalists about land planarians was probably the reason. It is significant, in this respect, that the

564 first recent mention of land planarians in France, by one of us (PG) was made public in an

565 internet forum dedicated to insects. We expect that the measures taken at the European level will

566 increase information about land planarians in the future (Tsiamis et al. 2016).

\section{Conclusion}

568 In this paper, we reported five species of Bipaliine worms from Metropolitan France, a few

569 European countries, and overseas French territories in three continents (Figures 1, 27, 28): much 
570 remains to be done, including a formal description of the two unnamed species. Of course, the

571 results recorded here are only a very small part of the spread of these invasive species in the

572 World. Initiatives like ours, including Citizen Science and molecular studies of selected

573 specimens, should be undertaken worldwide. We have shown that molecular barcoding, based on

574 COI, was efficient for the identification of the five species studied here, thus providing tools for

575 future studies. We presented evidence that several species are spreading and that at least one of

576 them is a predator of earthworms, which are important constituents of the soil fauna (Jones et al.

577 2001; Murchie \& Gordon 2013). We also demonstrated that bipaliines correspond well with the

578 definition of "Invasive Alien Species" in the European scientific (Kettunen et al. 2009) and legal

579 (European Parliament 2014) documents, but we recognize that a precise assessment of their

580 impact on the local biodiversity is needed - but is outside the scope of this paper. Recently, a

581 tendency to deny the risks posed by non-native species has emerged (Ricciardi \& Ryan 2018); in

582 opposition to this 'denialism', we strongly believe that invasive flatworms, as active predators,

583 constitute a danger to native fauna wherever they are introduced.

584

\section{Acknowledgements}

586 We thank all the citizens who participated in the survey; those who sent specimens are

587 particularly thanked. Names of citizens, and sometimes scientists, who provided photographs

588 and/or specimens are indicated in Tables 2, 5-8 and in the Supplemental Files. We apologize for

589 not mentioning the names of citizens who kindly provided information but could not be

590 contacted later for obtaining a formal consent. The support of various Fédérations Régionales de

591 Défense contre les Organismes Nuisibles (FREDON), in Metropolitan France and overseas

592 departments, is acknowledged. LW thanks Martin Darley for the specimen of Bipalium kewense

593 from Pakistan. 
595 References

596 Álvarez-Presas M, Carbayo F, Rozas J, and Riutort M. 2011. Land planarians (Platyhelminthes)

597

598

599

600

601

602

603

604

605

606

607

608

609

610

611

612

613

614

615

616

617 Boag B, Palmer LF, Neilson R, and Chambers SJ. 1994. Distribution and prevalence of the 618 619 as a model organism for fine-scale phylogeographic studies: understanding patterns of biodiversity in the Brazilian Atlantic Forest hotspot. Journal of Evolutionary Biology 24:887-896.

Álvarez-Presas M, Mateos E, Tudo A, Jones H, and Riutort M. 2014. Diversity of introduced terrestrial flatworms in the Iberian Peninsula: a cautionary tale. PeerJ 2:e430.

Álvarez-Presas M, Mateos E, Vila-Farré M, Sluys R, and Riutort M. 2012. Evidence for the persistence of the land planarian species Microplana terrestris (Müller, 1774) (Platyhelminthes, Tricladida) in microrefugia during the Last Glacial Maximum in the northern section of the Iberian Peninsula. Molecular Phylogenetics and Evolution 64:491-499.

Álvarez-Presas M, and Riutort M. 2014. Planarian (Platyhelminthes, Tricladida) diversity and molecular markers: a new view of an old group. Diversity 6:323-338.

Ayadi ZEM, Gey D, Justine J-L, and Tazerouti F. 2017. A new species of Microcotyle (Monogenea: Microcotylidae) from Scorpaena notata (Teleostei: Scorpaenidae) in the Mediterranean Sea. Parasitology International 66:37-42.

Blackburn TM, Essl F, Evans T, Hulme PE, Jeschke JM, Kühn I, Kumschick S, Marková Z, Mrugała A, Nentwig W, Pergl J, Pyšek P, Rabitsch W, Ricciardi A, Richardson DM, Sendek A, Vilà M, Wilson JRU, Winter M, Genovesi P, and Bacher S. 2014. A unified classification of alien species based on the magnitude of their environmental impacts. PLoS Biology 12:e1001850. predatory planarian Artioposthia triangulata (Dendy) (Tricladida: Terricola) in Scotland. Annals of Applied Biology 124:165-171. 
620 Bowles J, Blair D, and McManus DP. 1995. A molecular phylogeny of the human schistosomes. Molecular Phylogenetics and Evolution 4:103-109.

622 Breugelmans K, Quintana Cardona J, Artois T, Jordaens K, and Backeljau T. 2012. First report 623 of the exotic blue land planarian, Caenoplana coerulea (Platyhelminthes, Geoplanidae), on Menorca (Balearic Islands, Spain). Zookeys 199:91-105.

625

626

627

628

629

630

631

632

633

634

635

636

637

638

639

640

641

642

643

644

Carbayo F, Alvarez-Presas M, Jones HD, and Riutort M. 2016. The true identity of Obama (Platyhelminthes: Geoplanidae) flatworm spreading across Europe. Zoological Journal of the Linnean Society 177:5-28.

Chaabane A, Neifar L, Gey D, and Justine J-L. 2016. Species of Pseudorhabdosynochus (Monogenea, Diplectanidae) from groupers (Mycteroperca spp., Epinephelidae) in the Mediterranean and Eastern Atlantic Ocean, with special reference to the "beverleyburtonae group" and description of two new species. PLOS ONE 11:e0159886.

Connella JV, and Stern DH. 1969. Land planarians: Sexuality and occurrence. Transactions of the American Microscopical Society 88:309-311.

Convention on Biological Diversity. 2018. What are Invasive Alien Species? https://www.cbd.int/invasive/WhatareIAS.shtml consulted 14/02/2018.

de Beauchamp P. 1962. Platydemus manokwari n. sp., planaire terrestre de la Nouvelle-Guinée Hollandaise. Bulletin de la Société Zoologique de France 87:609-615.

Dendy A. 1891. Short descriptions of new Land Planarians. Proceedings of the Royal Society of Victoria, pp. 35-38.

Dendy A. 1895. Notes on New Zealand Land Planarians: Part II. Transactions of the Royal Society of New Zealand 28:210-214.

Ducey PK, Messere M, Lapoint K, and Noce S. 1999. Lumbricid prey and potential herpetofaunal predators of the invading terrestrial flatworm Bipalium adventitium (Turbellaria: Tricladida: Terricola). American Midland Naturalist 141:305-314. 
645 European Parliament. 2014. Regulation (EU) No 1143/2014 of the European Parliament and of

646

647

648

649

650

651

652

653

654

655

656

657

658

659

660

661

662

663

664

665

666

667

668 the Council of 22 October 2014 on the prevention and management of the introduction and spread of invasive alien species. Official Journal of the European Union:L 317/335L 317/355, available at: http://data.europa.eu/eli/reg/2014/1143/oj in various languages.

Executive Order 13112. 1999. Executive Order 13112 of February 3, 1999, Invasive Species. Federal Register / Vol. 64, No. 25 / Monday, February 8, 1999 / Presidential Documents, p. 6183-6186, available at: https://www.gpo.gov/fdsys/pkg/FR-1999-02-08/pdf/993184.pdf, consulted 14/02/2018.

Gerlach J. 2017. Partula survival in 2017, a survey of the Society islands. Published by the author (29pp) - available from https://islandbiodiversitycom/; dowloaded 10 November 2017.

Gremigni V. 2003. Turbellaria. In: Stoch F, ed. Checklist of the species of the Italian fauna Online Version 20 http://wwwfaunaitaliait/checklist/indexhtml.

Hebert PDN, Cywinska A, Ball SL, and deWaard JR. 2003. Biological identifications through DNA barcodes. Proceedings of the Royal Society of London Series B: Biological Sciences 270:313-321.

Hebert PDN, and Gregory TR. 2005. The promise of DNA barcoding for taxonomy. Systematic Biology 54:852-859.

Hyman LH. 1951. The Invertebrates: Platyhelminthes and Rhynchocoela. New York: MacGrawHill.

Infoclimat A. 2017. Normes et records 1961-1990. Available at https://www.infoclimat.fr/, consulted 10 November 2017.

International Union for Conservation of Nature. 2018. Invasive species, available at: https://www.iucn.org/theme/species/our-work/invasive-species, consulted 14/02/2018. 
669 Johri LN. 1952. A report on a Turbellarian Placocephalus kewense, from Delhi State and its

670

671

672

673

674

675

676

677

678

679

680

681

682

683

684

685

686

687

688

689

690

691

692

feeding behaviour on the live earthworm Pheretima posthume. Science and Culture (Calcutta) 18:291.

Jones HD. 1999. A new genus and species of terrestrial planarian (Platyhelminthes; Tricladida; Terricola) from Scotland, and an emendation of the genus Artioposthia. Journal of Natural History 33:387-394.

Jones HD, Santoro G, Boag B, and Neilson R. 2001. The diversity of earthworms in 200 Scottish fields and the possible effect of New Zealand land flatworms (Arthurdendyus triangulatus) on earthworm populations. Annals of Applied Biology 139:75-92.

Jones HD, and Sluys R. 2016. A new terrestrial planarian species of the genus Marionfyfea (Platyhelminthes: Tricladida) found in Europe. Journal of Natural History 50:2673-2690.

Jones HD, and Sterrer W. 2005. Terrestrial planarians (Platyhelminthes, with three new species) and nemertines of Bermuda. Zootaxa 1001:31-58.

Justine J-L. 2017. Plathelminthes terrestres invasifs. Blog (in French). https://sites.google.com/site/jljjustine/plathelminthe-terrestre-invasif.

Justine J-L, Thévenot J, and Winsor L. 2014a. Les sept plathelminthes invasifs introduits en France. Phytoma:28-32 doi:10.6084/m6089.figshare.1447202.

Justine J-L, Winsor L, Barrière P, Fanai C, Gey D, Han AWK, La Quay-Velazquez G, Lee BPYH, Lefevre J-M, Meyer J-Y, Philippart D, Robinson DG, Thévenot J, and Tsatsia F. 2015. The invasive land planarian Platydemus manokwari (Platyhelminthes, Geoplanidae): records from six new localities, including the first in the USA. PeerJ 3:e1037.

Justine J-L, Winsor L, Gey D, Gros P, and Thévenot J. 2014b. The invasive New Guinea flatworm Platydemus manokwari in France, the first record for Europe: time for action is now. PeerJ 2:e297. 
693 Kawakatsu M, Makino N, and Shirasawa Y. 1982. Bipalium nobile sp. nov. (Turbellaria, 694 Tricladida, Terricola), a new land planarian from Tokyo. Annotationes Zoologicae 695 Japonense 55:236-262.

696 Kawakatsu M, Ogren RE, Froehlich EM, and Sasaki G-Y. 2002. Additions and corrections of the 697 previous land planarian indices of the world (Turbellaria, Seriata, Tricladida, Terricola).

Kawakatsu M, Sluys R, and Ogren RE. 2005. Seven new species of land planarian from Japan and China (Platyhelminthes, Tricladida, Bipaliidae), with a morphological review of all Japanese bipaliids and a biogeographic overview of Far Eastern species. Belgian Journal

703 Bulletin of the Fuji Women's College (Series 2) 40:157-177. of Zoology 135:53-77.

Kettunen M, Genovesi P, Gollasch S, Pagad S, Starfinger U, ten Brink P, and Shine C. 2009. Technical support to EU strategy on invasive alien species (IAS) - Assessment of the impacts of IAS in Europe and the EU (final module report for the European Commission). Brussels, Belgium: Institute for European Environmental Policy (IEEP).

Košel V. 2002. Checklist of turbellaria in Slovakia. Acta Zoologica Universitatis Comenianae 44:37-40.

Kubota S, and Kawakatsu M. 2010. Distribution record of a single species of the collective group Diversibipalium (Plathelminthes, Tricladida, Continenticola, Geoplanidae, Bipaliinae) in Wakayama Prefecture, Honshu, Japan, with a taxonomic note of new higher classification of the Tricladida. Nanki Seibutsu 52:97-101.

Kumar S, Stecher G, and Tamura K. 2016. MEGA7: Molecular Evolutionary Genetics Analysis version 7.0 for bigger datasets. Molecular Biology and Evolution 33:1870-1874.

Lázaro EM, Sluys R, Pala M, Stocchino GA, Baguñà J, and Riutort M. 2009. Molecular barcoding and phylogeography of sexual and asexual freshwater planarians of the genus Dugesia in the Western Mediterranean (Platyhelminthes, Tricladida, Dugesiidae). Molecular Phylogenetics and Evolution 52:835-845. 
719 Littlewood DTJ, Rohde K, and Clough KA. 1997. Parasite speciation within or between host

720

721

722

723

724

725

726

727

728

729

730

731

732

733

734

735

736

737

738

739

740

741

742

743

744 species? - Phylogenetic evidence from site-specific polystome monogeneans. International Journal for Parasitology 27:1289-1297.

Makino N, and Shirasawa Y. 1983. Morphological and ecological comparison with two new species of elongated slender land planarians have several stripes and their new scientific names. Bulletin of Tokyo Medical College 9:69-83 [In Japanese, English summary].

Mateos E, Tudó A, Álvarez-Presas M, and Riutort M. 2013. Planàries terrestres exòtiques a la Garrotxa. Annals de la Delegació de la Garrotxa de la Institució Catalana d'Història Natural 6:67-73.

Mazza G, Menchetti M, Sluys R, Solà E, Riutort M, Tricarico E, Justine J-L, Cavigioli L, and Mori E. 2016. First report of the land planarian Diversibipalium multilineatum (Makino \& Shirasawa, 1983) (Platyhelminthes, Tricladida, Continenticola) in Europe. Zootaxa 4067:577-580.

Morffe J, García N, Adams BJ, and Hasegawa K. 2016. First record of the land planarian Bipalium kewense Moseley, 1878 (Tricladida: Geoplanidae: Bipaliinae) from Cuba. BioInvasions Records 5:127-132.

Moseley H. 1877. Notes on the structure of several forms of land planarians, with a description of two new genera and several new species, and a list of all species at present known. Quarterly Journal of Microscospical Science 17:273-292.

Moseley HN. 1878. Description of a new species of land-planarian from the hothouses at Kew Gardens. Annals and Magazine of Natural History 1:237-239.

Murchie AK, and Gordon AW. 2013. The impact of the "New Zealand flatworm", Arthurdendyus triangulatus, on earthworm populations in the field. Biological Invasions 15:569-586.

Ricciardi A, and Ryan R. 2018. The exponential growth of invasive species denialism. Biological Invasions 3:549-553 
745 Saitou N, and Nei M. 1987. The neighbor-joining method: a new method for reconstructing phylogenetic trees. Molecular Biology and Evolution 4:406-425.

747 Sluys R. 2016. Invasion of the Flatworms. American Scientist 104:288-295.

748

749

750

751

752

753

754

755

756

757

758

759

760

761

762

763

764

765

766

767

768

769

770

771

Stokes AN, Ducey PK, Neuman-Lee L, Hanifin CT, French SS, Pfrender ME, Brodie ED, III, and Brodie Jr ED. 2014. Confirmation and distribution of Tetrodotoxin for the first time in terrestrial invertebrates: Two terrestrial flatworm species (Bipalium adventitium and Bipalium kewense). PLoS ONE 9:e100718.

Tsiamis K, Gervasini E, D’Amico F, Deriu I, Katsanevakis S, Crocetta F, Zenetos A, Arianoutsou M, Backeljau T, Bariche M, Bazos I, Bertaccini A, Brundu G, Carrete M, Çinar ME, Curto G, Faasse M, Justine J-L, Király G, Langer MR, Levitt Ya, Panov VE, Piraino S, Rabitsch W, Roques A, Scalera R, Shenkar N, Sîrbu I, Tricarico E, Vannini A, Vøllestad LA, Zikos A, and Cardoso AC. 2016. The EASIN Editorial Board: quality assurance, exchange and sharing of alien species information in Europe. Management of Biological Invasions 7:321-328.

Vanhove MP, Tessens B, Schoelinck C, Jondelius U, Littlewood DT, Artois T, and Huyse T. 2013. Problematic barcoding in flatworms: A case-study on monogeneans and rhabdocoels (Platyhelminthes). Zookeys:355-379.

Vivant J. 2005. Bipalium kewense Moseley, ver tropical terricole, existe à Orthez (Pyr. atl.). Bulletin de la Société Mycologique Landaise:46-48.

von Graff L. 1899. Monographie der Turbellarien. II. Tricladida, Terricola (Landplanarien). Leipzig: Englemann.

Ward RD, Zemlak TS, Innes BH, Last PR, and Hebert PD. 2005. DNA barcoding Australia's fish species. Philosophical Transactions of the Royal Society of London B Biological Sciences 360:1847-1857.

Winsor L. 1983a. A revision of the Cosmopolitan land planarian Bipalium kewense Moseley, 1878 (Turbellaria: Tricladida: Terricola). Zoological Journal of the Linnean Society 79:61-100. 
772 Winsor L. 1983b. Vomiting of land planarians (Turbellaria: Tricladida: Terricola) ingested by cats. Australian Veterinary Journal 60:282-283.

774 Winsor L. 1991. A provisional classification of Australian terrestrial geoplanid flatworms (Tricladida: Terricola: Geoplanidae). Victorian Naturalist (Blackburn) 108:42-49.

776 Winsor L, Johns PM, and Barker GM. 2004. Terrestrial planarians (Platyhelminthes: Tricladida: 777 Terricola) predaceous on terrestrial gastropods. In: Barker GM, ed. Natural enemies of

781

782

783

784

785

786

787

788

789
Winsor L, Johns PM, and Yeates GW. 1998. Introduction, and ecological and systematic background, to the Terricola (Tricladida). Pedobiologia 42 389-404.

terrestrial molluscs. Oxfordshire, UK: CAB International, 227-278.

Wizen G. 2015. Photograph. Caption: Huge terrestrial flatworm (Bipalium kewense), Mindo, Ecuador, March. Nature Picture Library, Image number 01504312. Available from: https://www.naturepl.com/search/preview/huge-terrestrial-flatworm-bipalium-kewensemindo-ecuador-march/0_01504312.html. Consulted on 06 Nov 2017.

Zaborski ER. 2002. Observations on feeding behavior by the terrestrial flatworm Bipalium adventitium (Platyhelminthes: Tricladida: Terricola) from Illinois. American Midland Naturalist 148:401-408. 


\section{Figure 1}

Map of Metropolitan France (including Corsica) showing records of bipaliine flatworms

Most records reported in this paper are outdoor but two are from hothouses. Note the concentration of records in the southern-east region, in the Department of PyrénéesAtlantiques.

\section{Outdoors}

- Bipalium kewense

- Diversibipalium multilineatum

• Diversibipalium sp."black"

\section{Hothouse}

Bipalium kewense

Diversibipalium multilineatum 


\section{Figure 2}

Evolutionary relationships of taxa

The tree shown was inferred using the Neighbour-Joining method. The percentage of replicate trees in which the associated taxa clustered together in the bootstrap test (1000 replicates) are shown next to the branches, only when $>70$. The evolutionary history inferred by Maximum Likelihood method had similar topology. In both trees, branches representing the four species with several samples (Bipalium kewense, Bipalium vagum, Diversibipalium multilineatum and Diversibipalium 'Blue') all had 100\% bootstrap values, but bootstrap values for upper nodes were very low. We consider that the tree is informative for showing the genetic identity of all specimens within a species, but not for inferring relationships between taxa. New records with molecular information are indicated by *. For records in Metropolitan France, the number indicates the department code (i.e. 64: PyrénéesAtlantiques). 


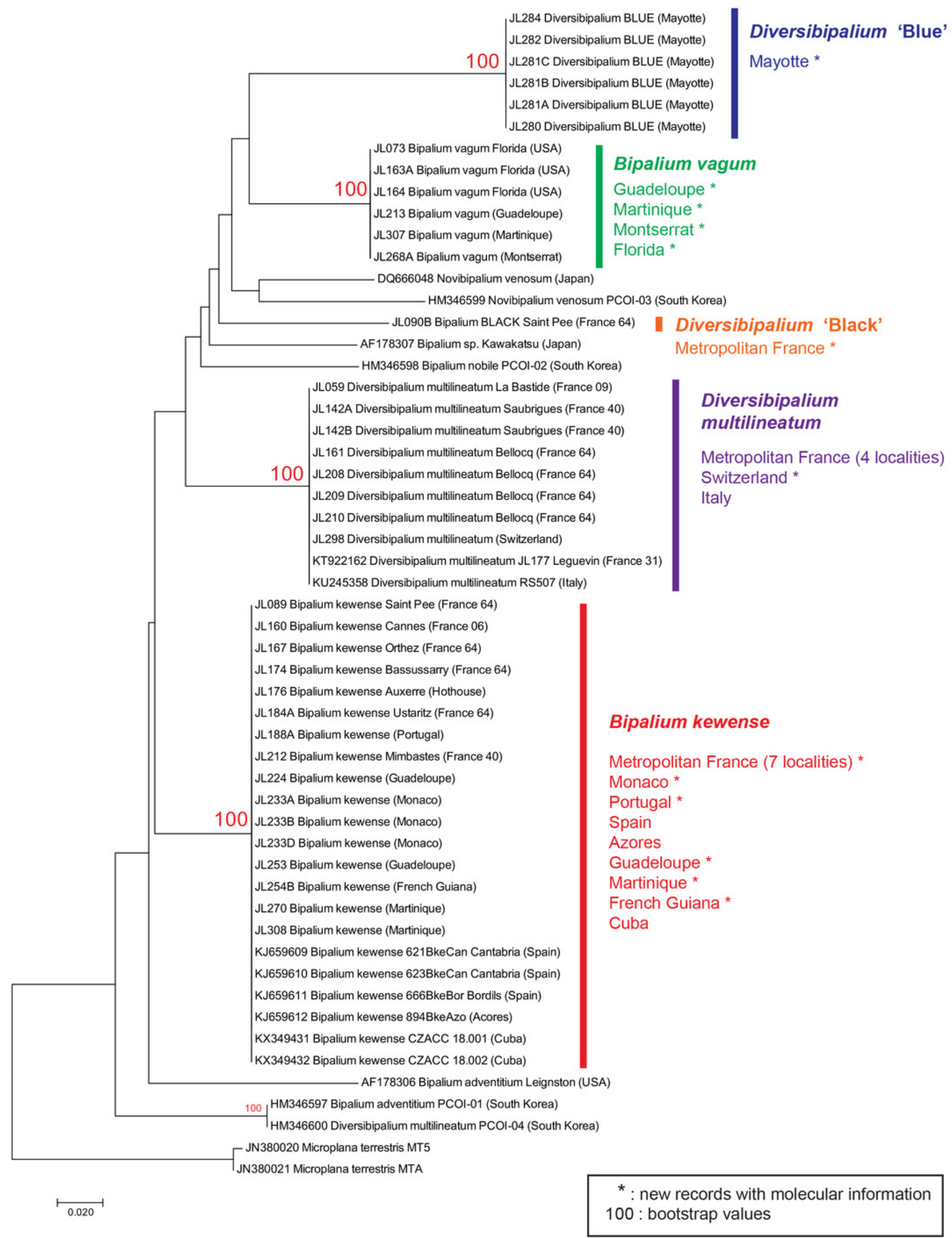




\section{Figure 3}

Bipalium kewense, general morphology.

Dorsal aspect of the planarian with a partial view of the ventral surface. Note the rounded posterior end indicating reproduction by scissiparity. Photo by Pierre Gros.

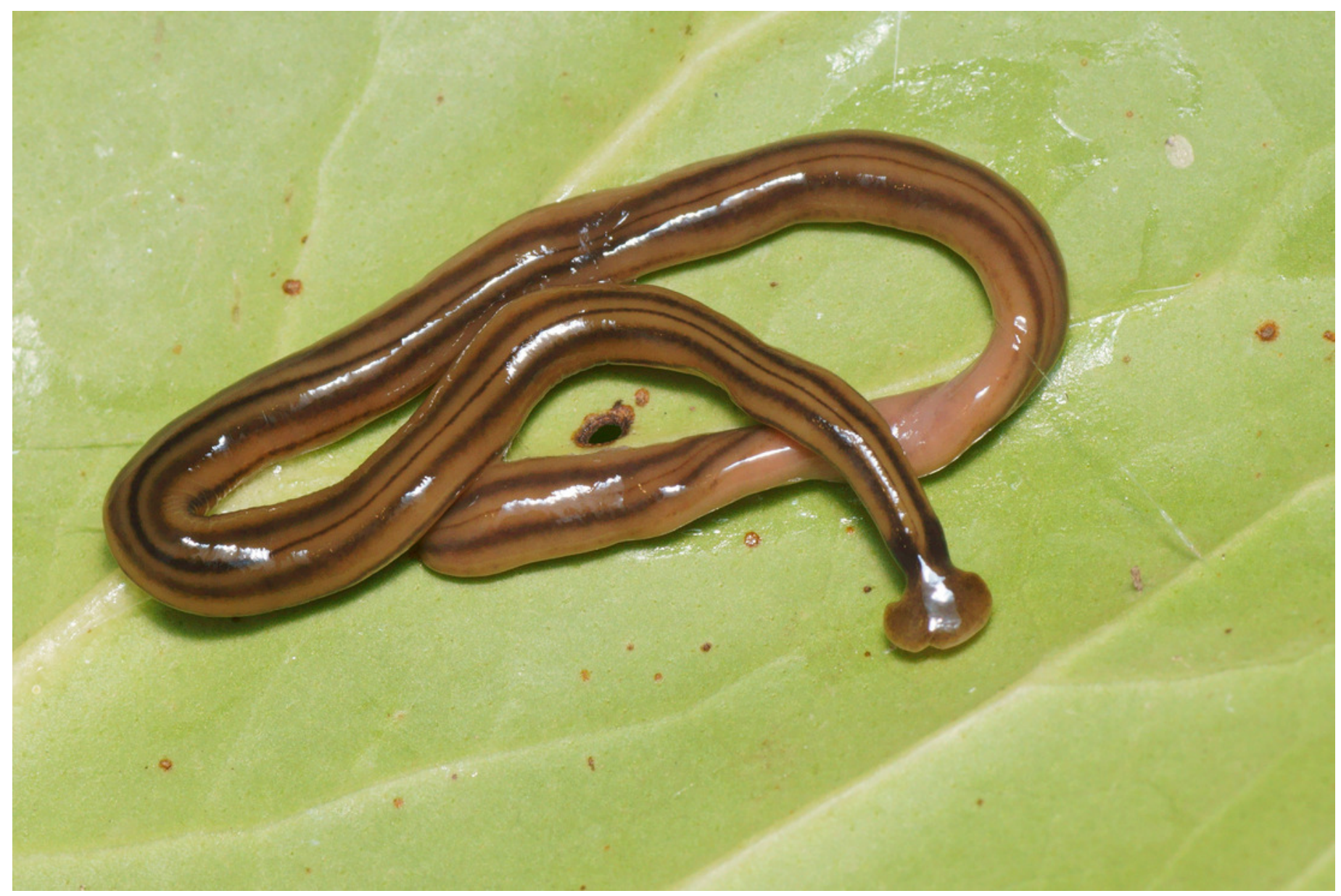




\section{Figure 4}

Bipalium kewense, general morphology of the dorsal anterior end.

The expanded headplate, transverse black band ("collar") at the neck, and the median, paired lateral and marginal dorsolateral dark longitudinal stripes are evident. Note that the median dorsal stripe does not pass onto the headplate. Photo by Pierre Gros.

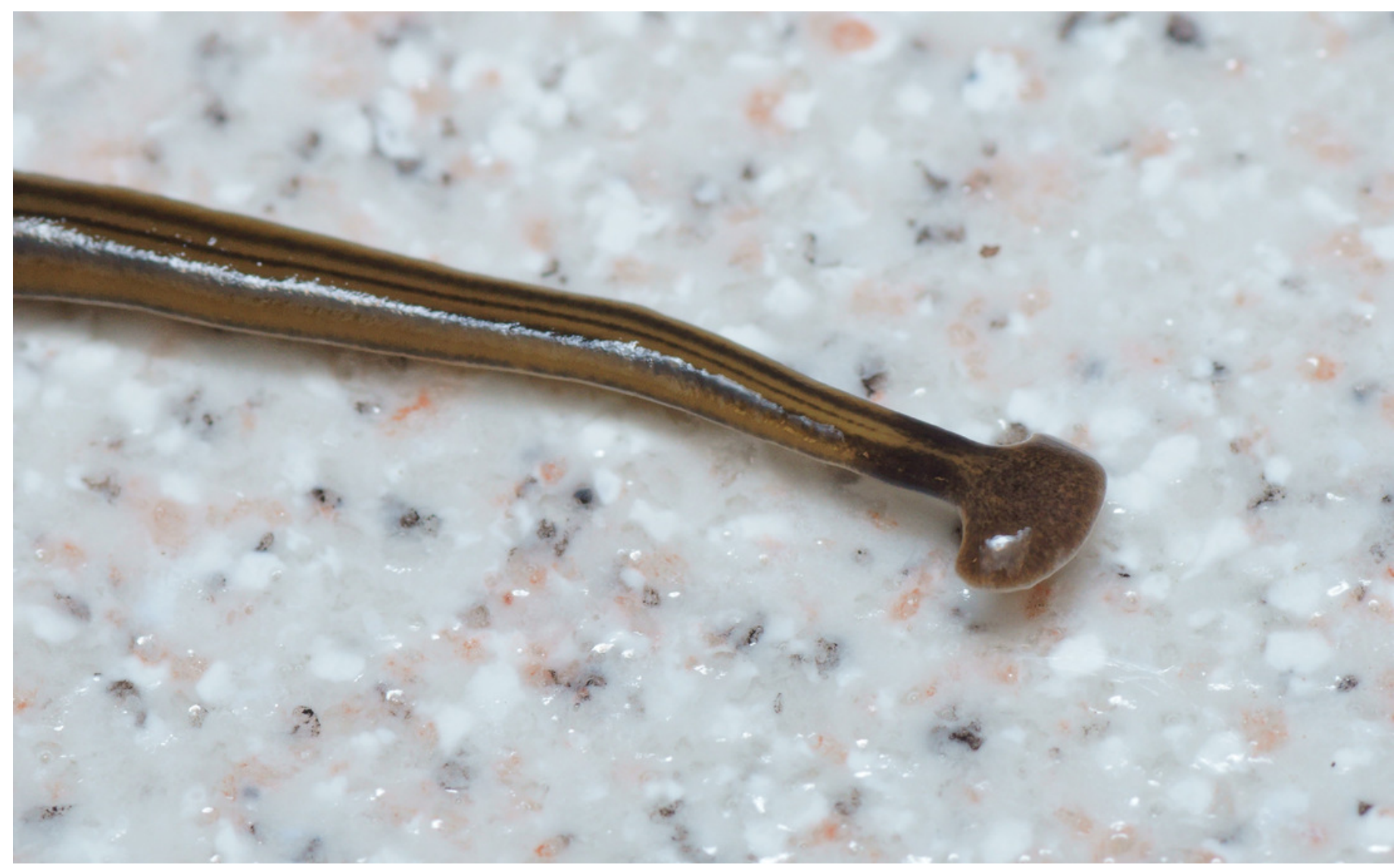




\section{Figure 5}

Bipalium kewense, side view of the headplate.

Bipalium kewense hunts its earthworm prey using mechanoreceptors and chemoreceptors located along the leading margin of the headplate. These receptors are exposed when the papillae around the headplate are distended and moved like stubby fingers in an undulating motion to sense the environment, seen in this image. The under surface of the headplate is richly endowed with a variety of glands that include secretions with adhesive, lubricating and probably toxin-related functions. Photo by Pierre Gros. 


\section{Figure 6}

Bipalium kewense, general morphology, ventral surface.

The dark transverse neck band is incomplete ventrally, and the paired diffuse grey-purplish stripes delineate the off-white creeping sole. The position of the mouth is indicated by *, and the approximate position of the plicate protrusible pharynx within the body is evident as the pale area either side of the mouth. Photo by Pierre Gros. 


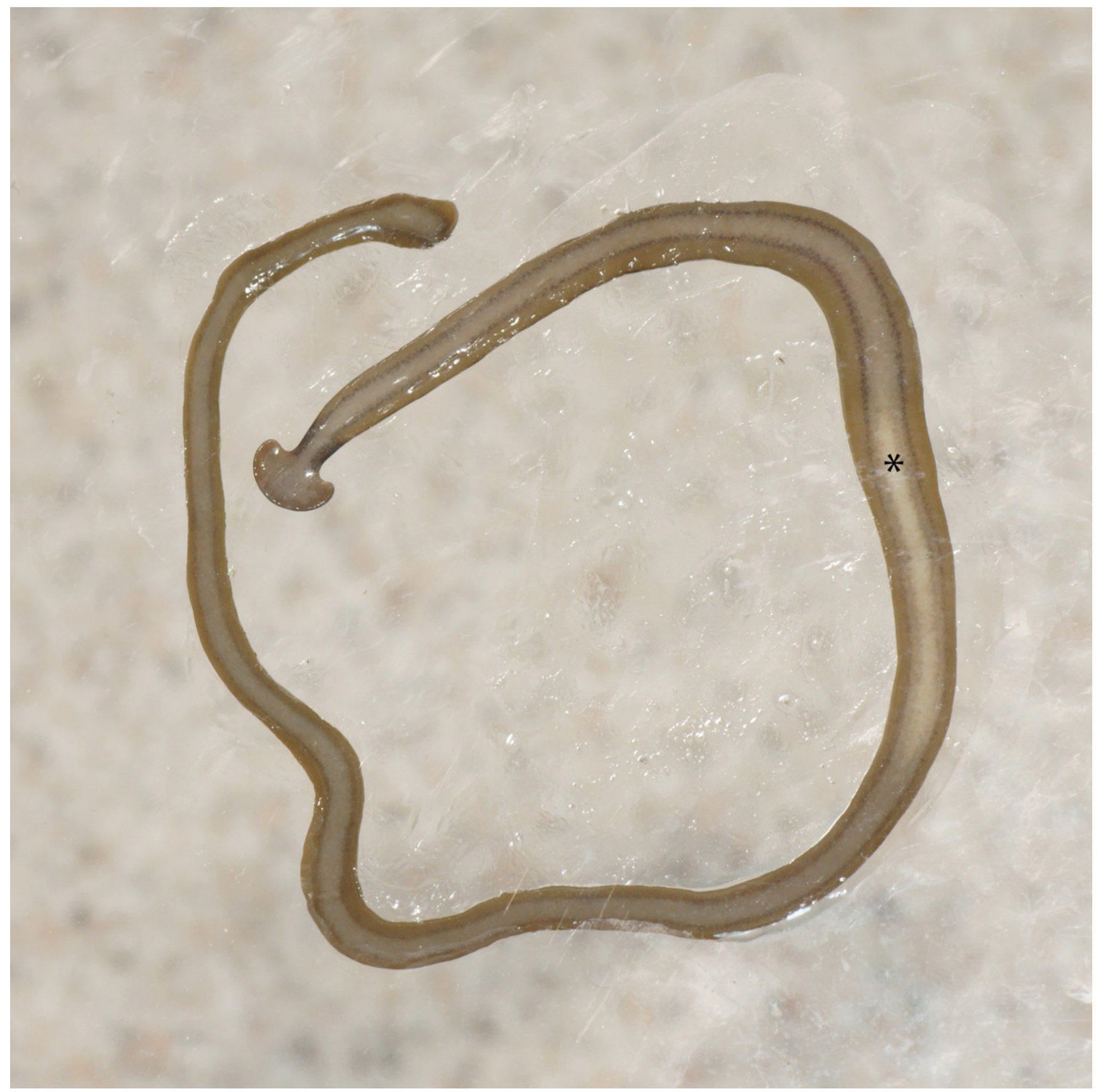




\section{Figure 7}

Bipalium kewense, predation on earthworm.

The flatworm initiates here the process of "capping" the anterior end of the earthworm. Observed reactions of the prey suggest that it is at this stage that the planarian secretes a toxin to reduce prey mobility (Stokes et al. 2014). The planarian also produces secretions from its headplate and body that adhere it to the prey, despite often sudden violent movements of the latter during this stage of capture. Photo by Pierre Gros.

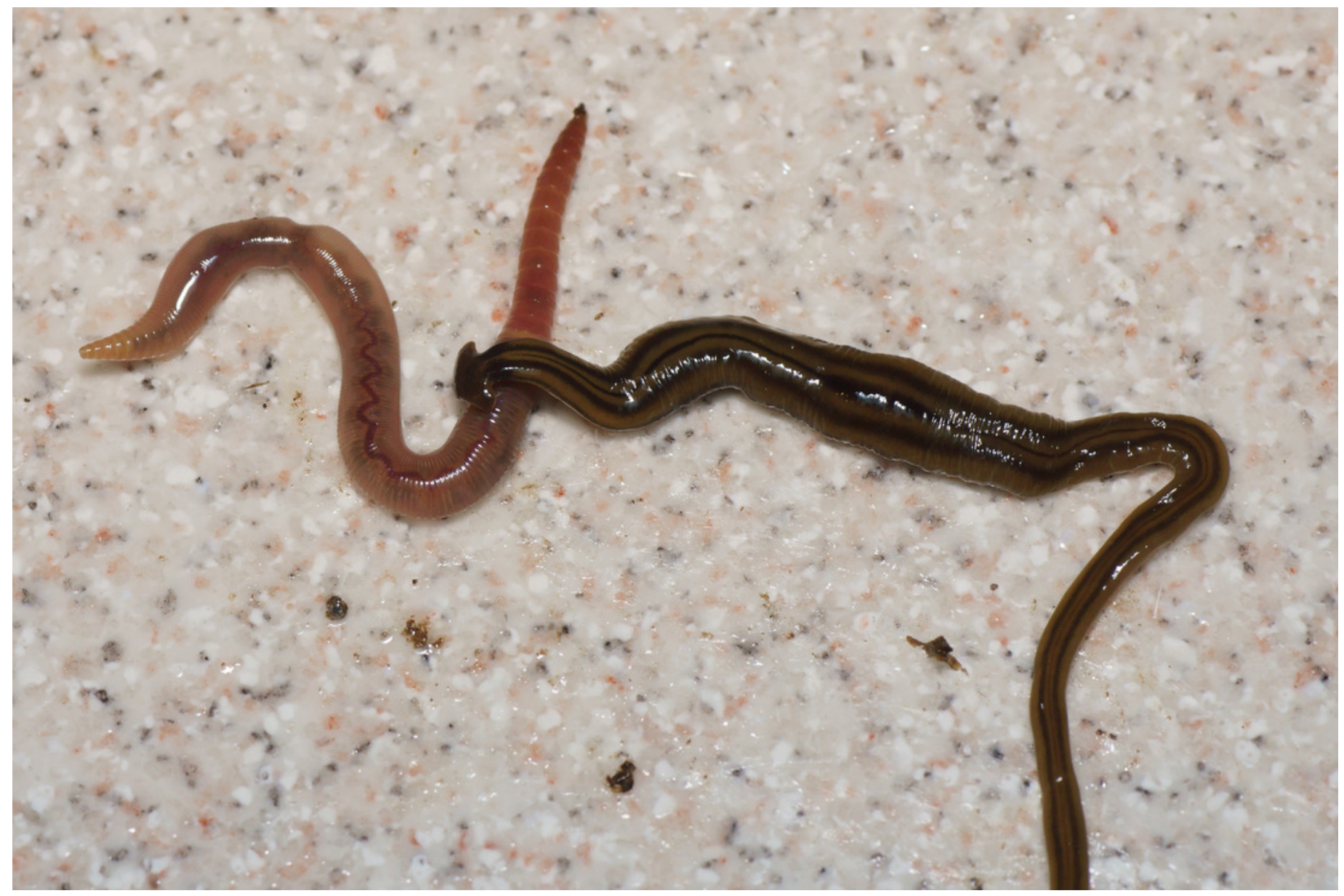




\section{Figure 8}

Bipalium kewense, reproduction by scissiparity.

Some 1-2 days following feeding, the fission process is first manifested by a slight pinching of the body, some $1-2 \mathrm{~cm}$. from the tail tip. Severance occurs when the tail tip adheres to the substratum and the rest of the planarian pulls away. Sexual reproduction outside their native habitat is restricted to individuals occupying outdoor situations in tropical or subtropical climates. Elsewhere they reproduce asexually. The links between sexuality and climate, and switching between scissiparity and egg cocoon production, indicate that several interacting factors are involved, not least the availability of food and climatic variability (Winsor et al. 2004). Photo by Pierre Gros.

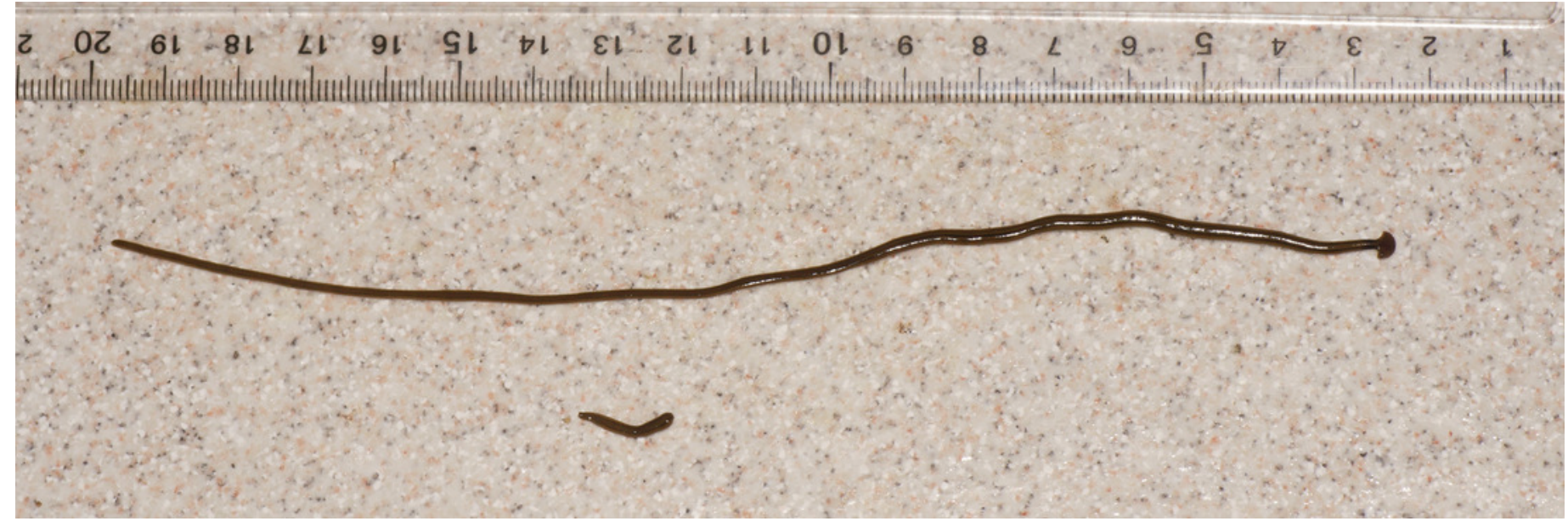




\section{Figure 9}

Bipalium kewense, reproduction by scissiparity - the shed tail fragment.

The free tail fragment is immediately motile. It develops a head and pharynx within 7-10 days, and within 23 weeks it is adult in form and behaviour (Connella \& Stern 1969). Asexual reproduction in B. kewense and some other land planarians is considered to underlie the colonizing success of these species (Hyman 1951) p. 163. Photo by Pierre Gros.

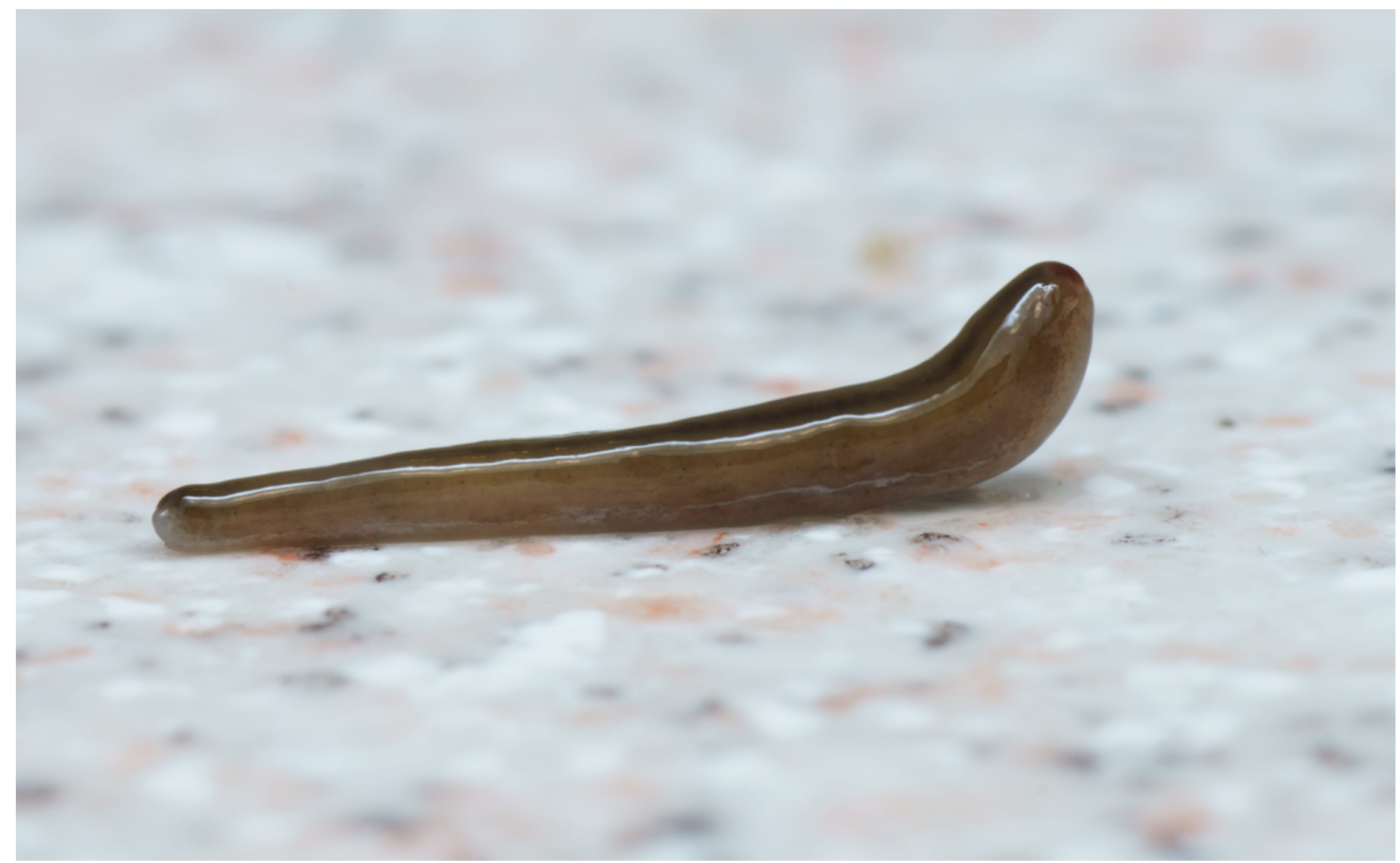




\section{Figure 10}

Diversibipalium multilineatum, general morphology.

Dorsal aspect with a partial view of the ventral surface. The dark dorsal median stripe extends onto the headplate, and the headplate is more rounded than the falciform headplate of Bipalium kewense. Note the rounded posterior end of the body indicating reproduction by scissiparity. Photo by Pierre Gros.

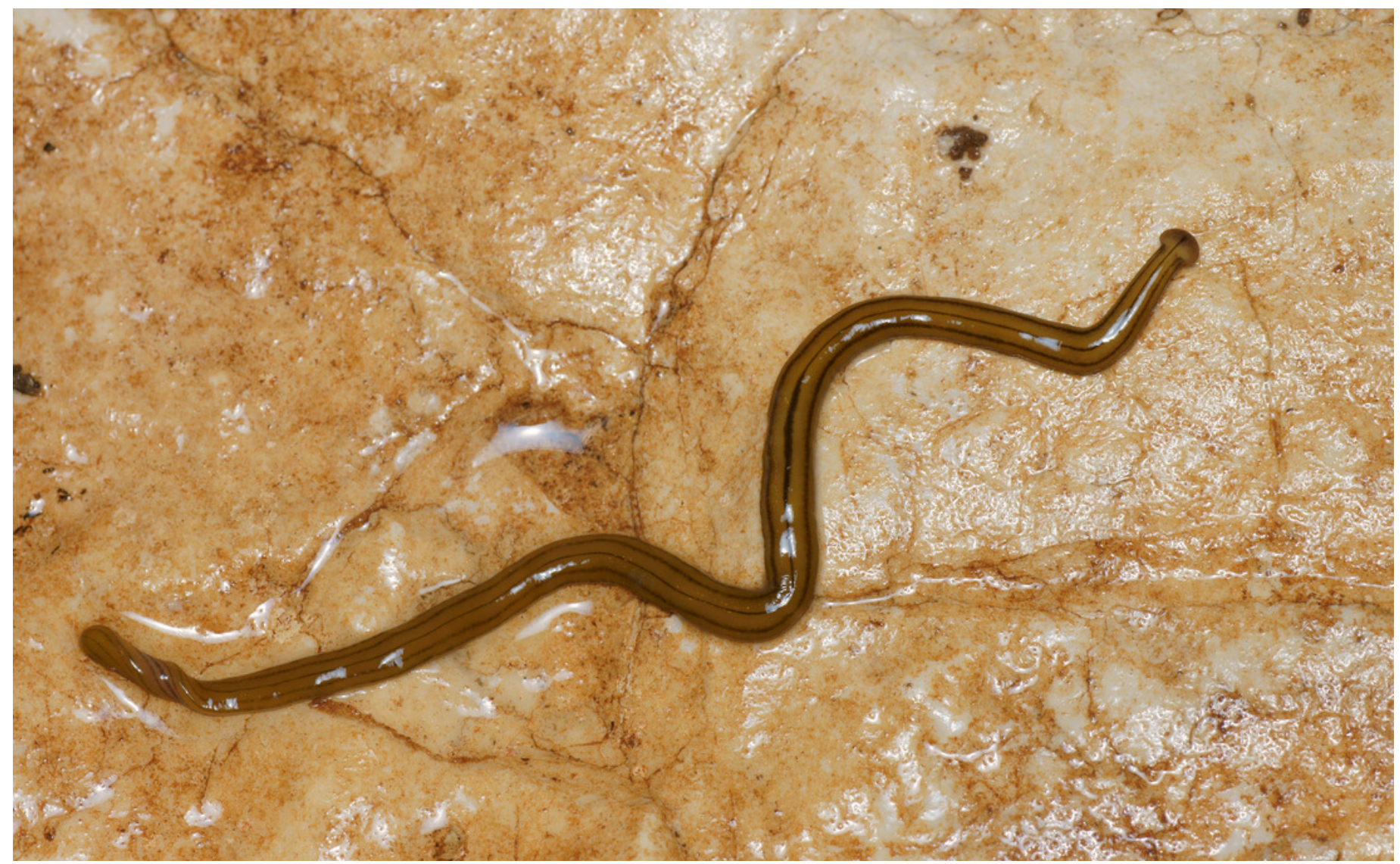




\section{Figure 11}

Diversibipalium multilineatum, headplate.

On the headplate, the dark median dorsal stripe begins at the anterior third of the headplate and has a pronounced characteristic oblanceolate shape. Photo by Pierre Gros. 


\section{Figure 12}

Diversibipalium multilineatum, general morphology, anterior end.

The lateral dorsal stripes begin immediately behind the headplate. A transverse dark band ("collar") is absent. Photo by Pierre Gros. 


\section{Figure 13}

Diversibipalium multilineatum, ventral headplate morphology.

The fine, generally discontinuous mid ventral dark stripe extends from the anterior third of the headplate to the posterior end. There are also faint indications of the beginnings of the ventral paired lateral stripes on the headplate. Photo by Pierre Gros.

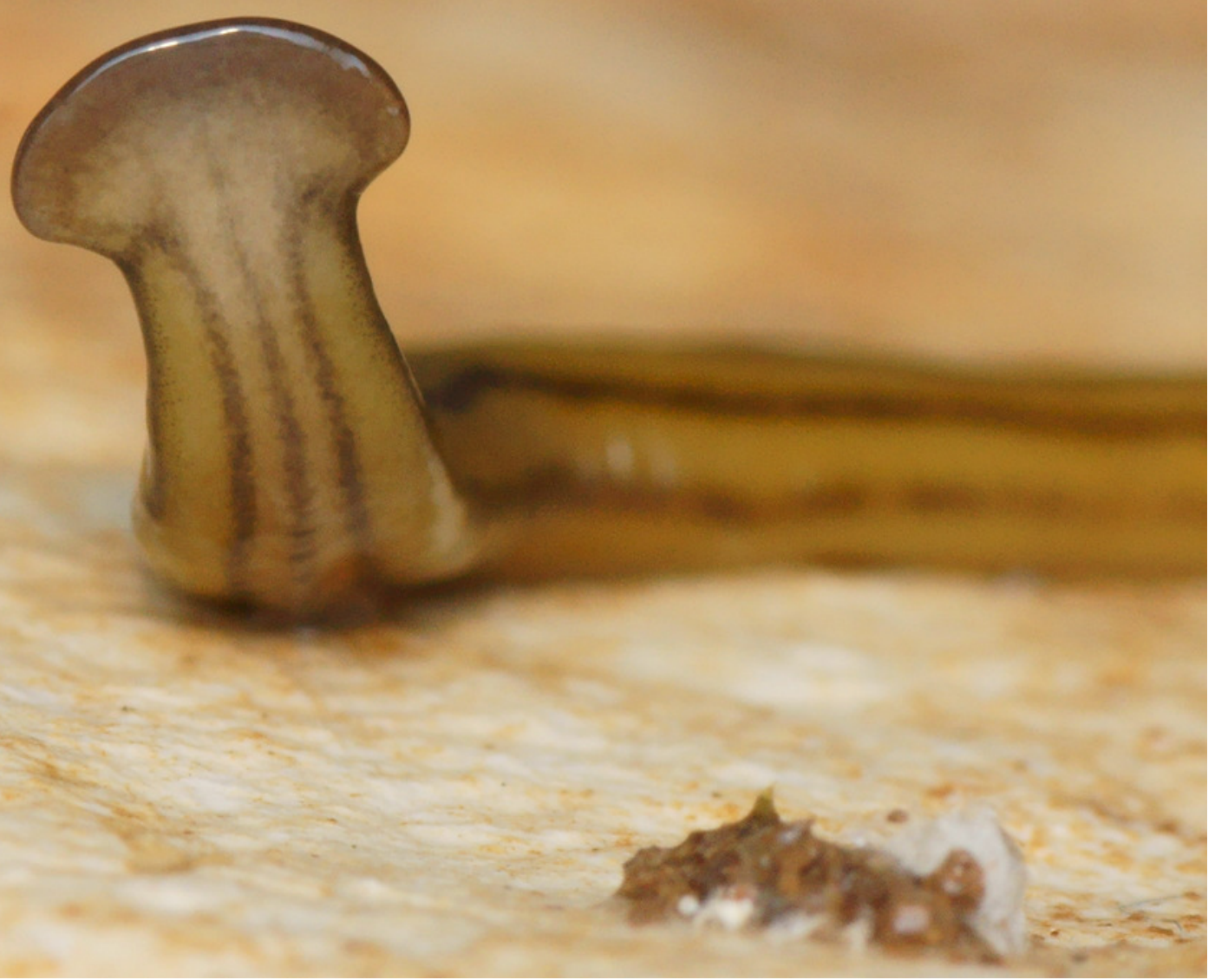




\section{Figure 14}

Diversibipalium multilineatum, general morphology, ventral surface.

The three dark longitudinal stripes begin at the "neck" and extend the length of the body.

The position of the mouth is indicated by *, and the approximate position of the plicate protrusible pharynx within the body is evident by the diffuse line of the median stripe in this region. Photo by Pierre Gros.

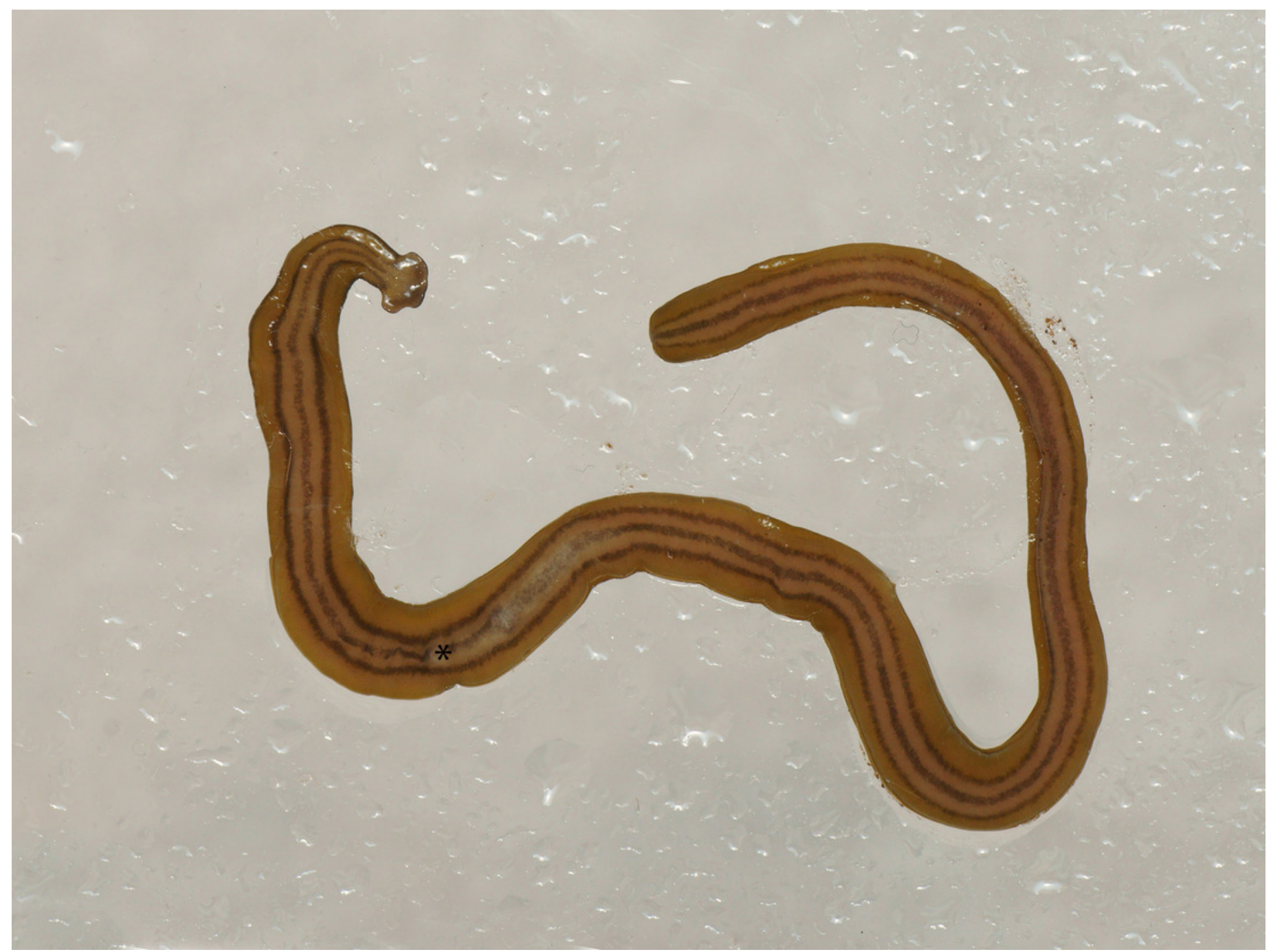




\section{Figure 15}

Bipalium vagum. Specimen from French Guiana.

The dorsal marking on this specimen are typical of the species. Note the dark patches on the headplate, continuous neckband, black median stripes, brown paired lateral stripes, and caudal black tip. Photo by Sébastien Sant, Parc Amazonien de Guyane.

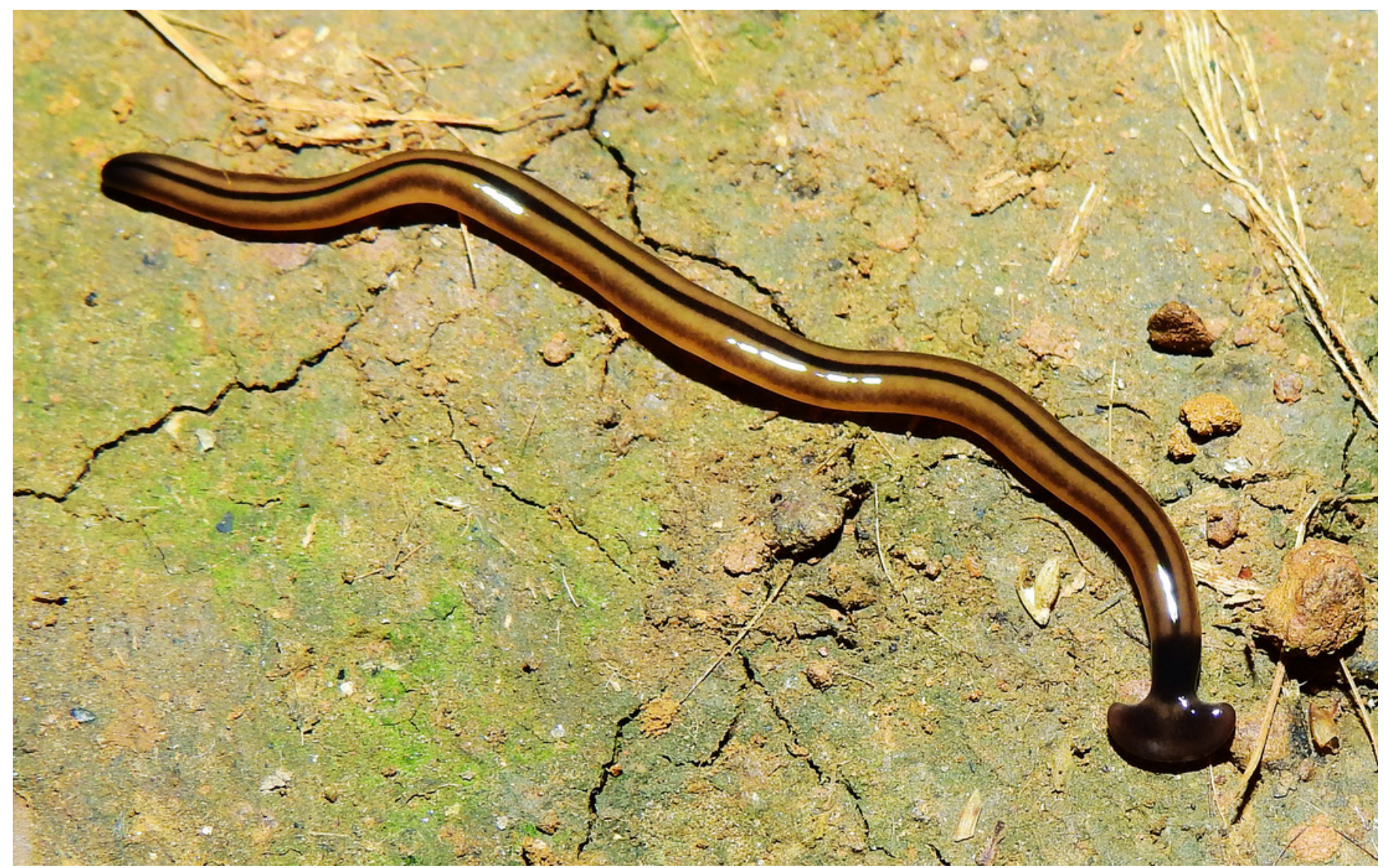




\section{Figure 16}

Bipalium vagum. Specimen from Guadeloupe, West Indies.

This specimen exhibits very light pigmentation, especially on the headplate, the indistinct brown paired lateral stripes and the caudal tip. Photo by Pierre and Claudine Guezennec.

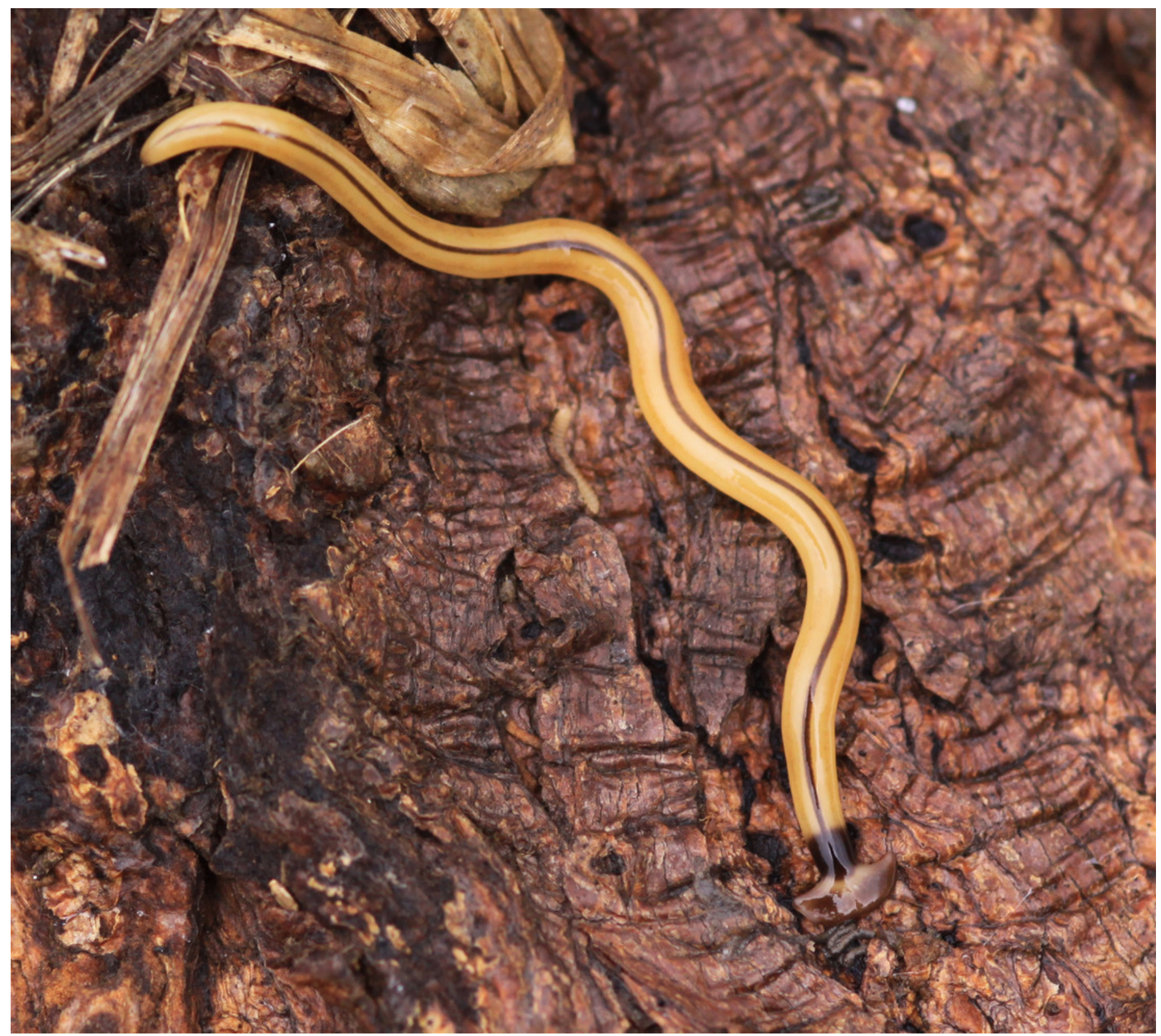




\section{Figure 17}

Bipalium vagum. Specimen from Martinique, West Indies.

In this specimen the headplate exhibits marked pigmentation so that it appears almost black. Photo Mathieu Coulis.

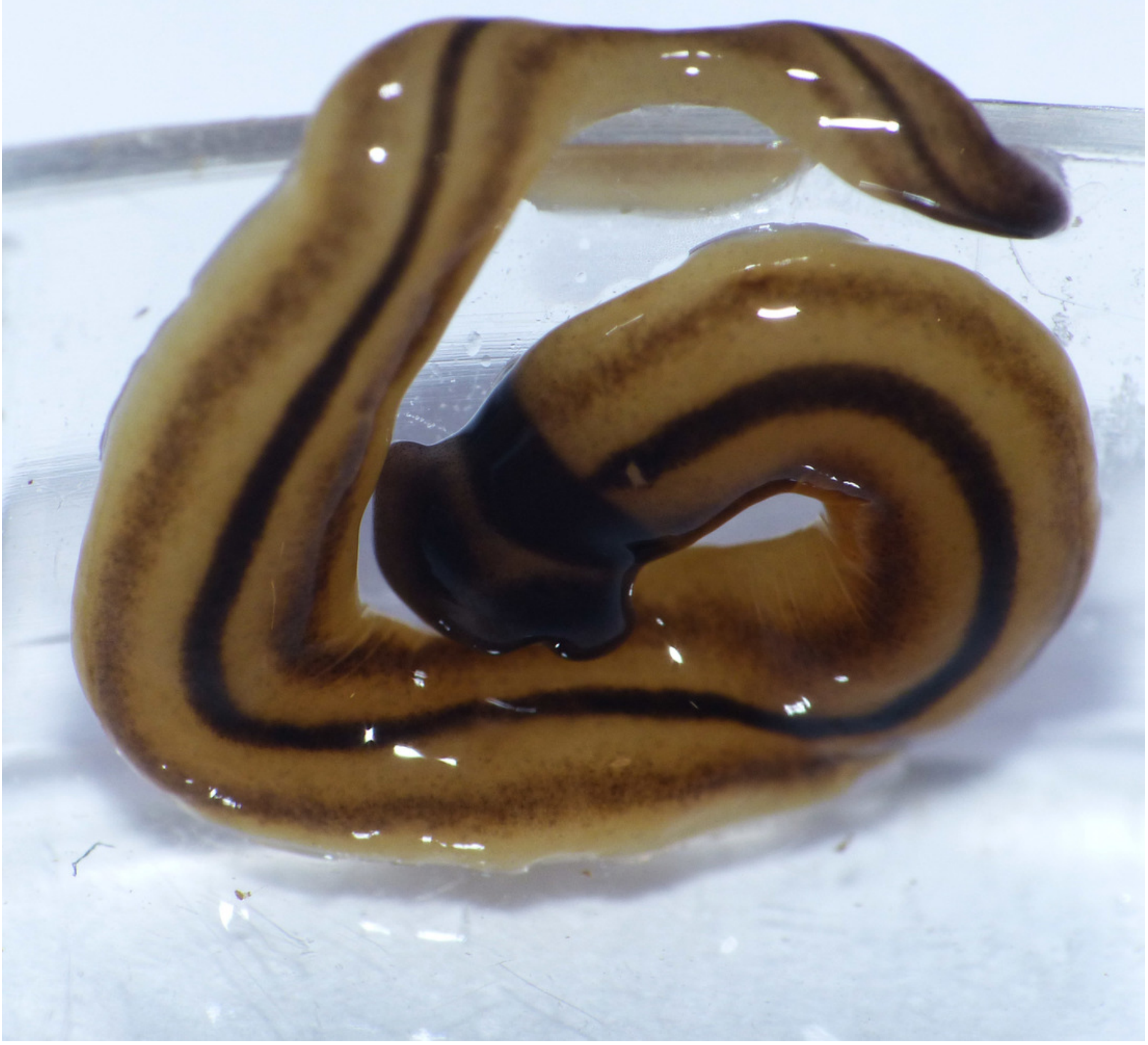




\section{Figure 18}

Bipalium vagum. Specimen from La Réunion, Indian Ocean.

This specimen exhibits typical markings of the species. The paired dark patches on the headplate, and the dark pigmented caudal tip are clearly shown. Photo by Dominique Martiré.

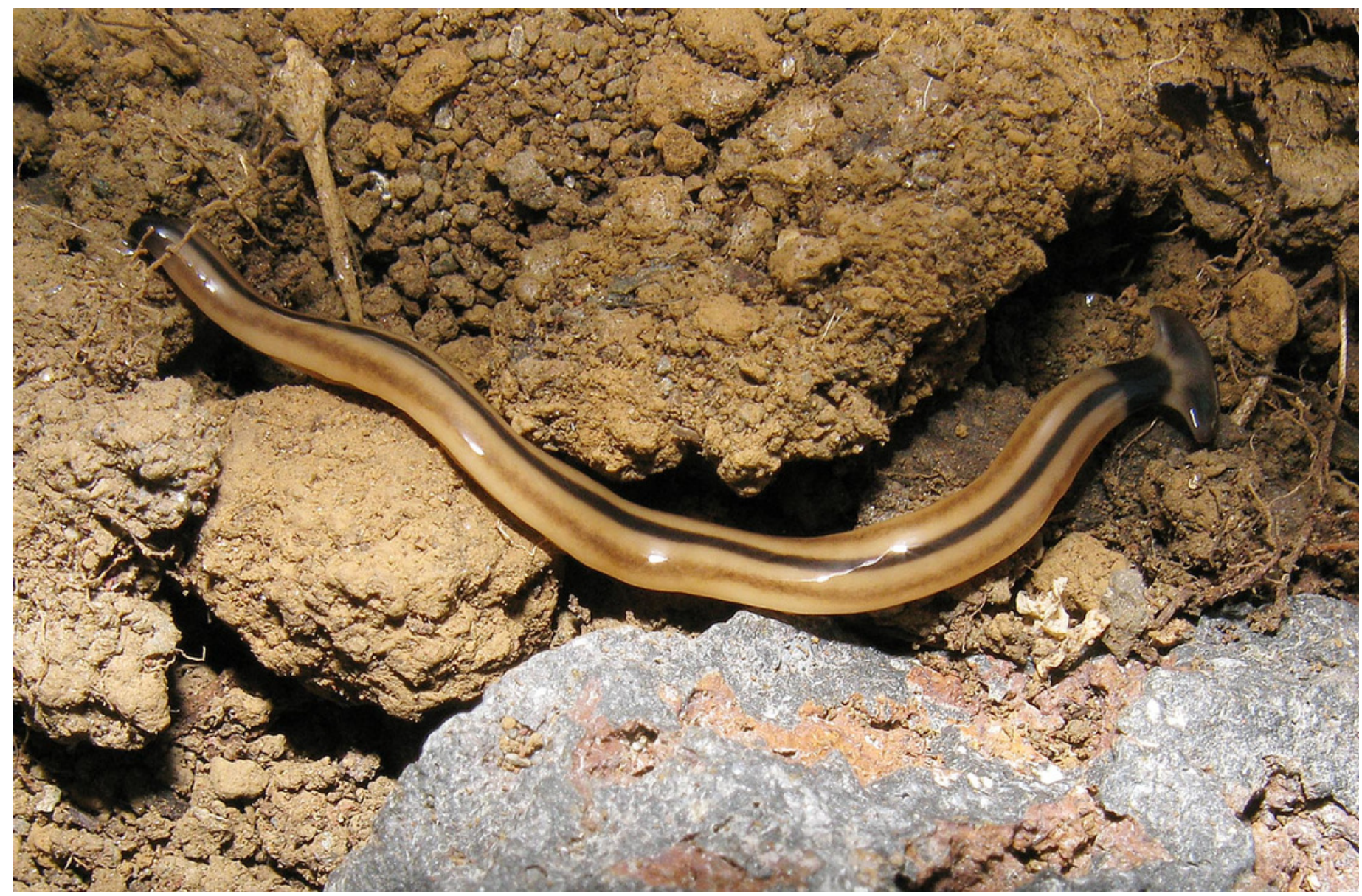




\section{Figure 19}

Diversibipalium sp. 'black' from Metropolitan France.

Drawings from photographs of three living specimens in dorsal view. The dorsal ground colour of the specimens is black, with no evidence of dorsal stripes. The scale $(10 \mathrm{~mm})$ is valid for the two specimens on the left, the specimen on the right has no scale.
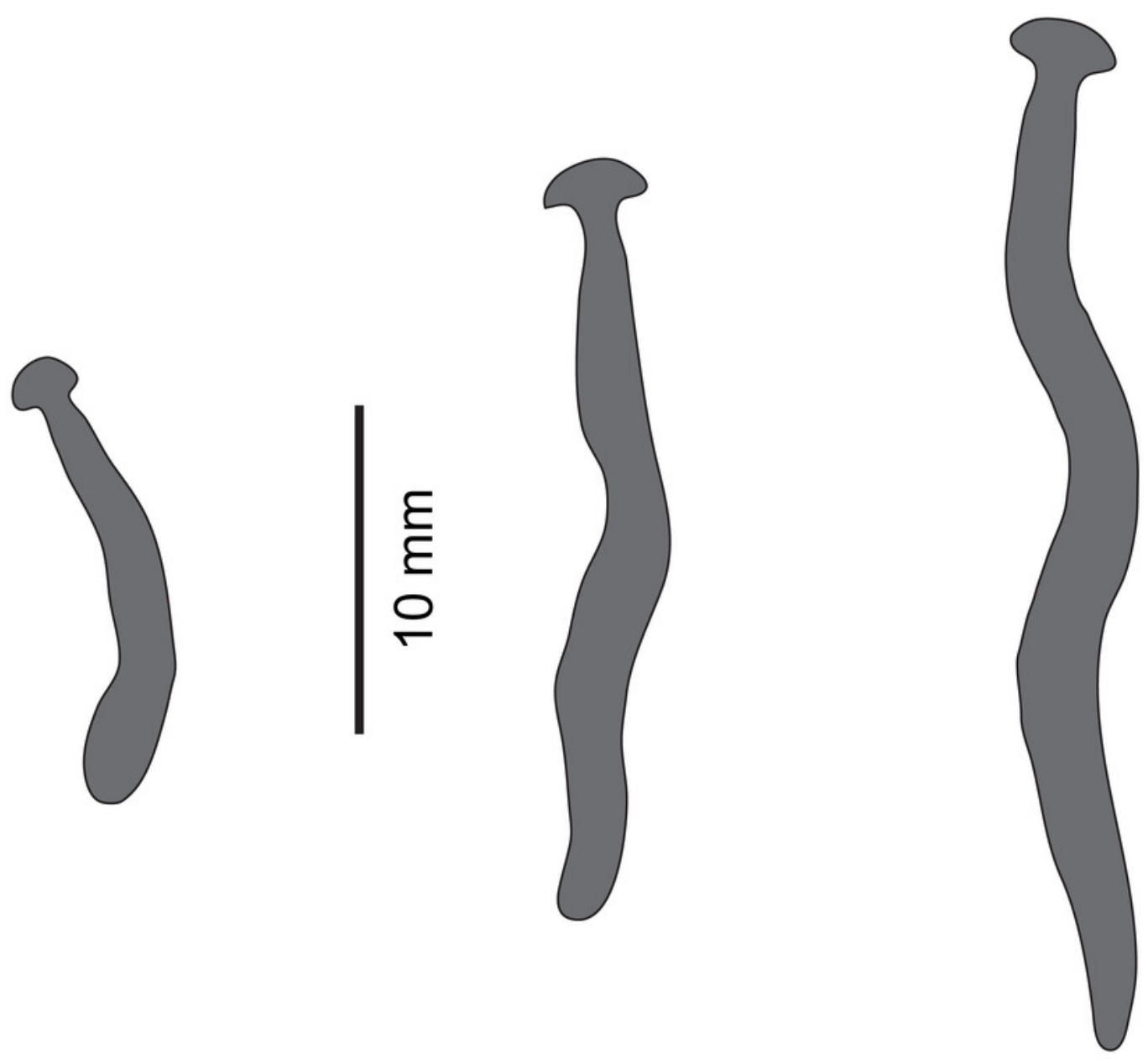


\section{Figure 20}

Diversibipalium sp. 'black' from Metropolitan France, preserved specimen.

Specimen MNHN JL090. Dorsolateral aspect showing the partly protruded pharynx. Photo by Jean-Lou Justine.

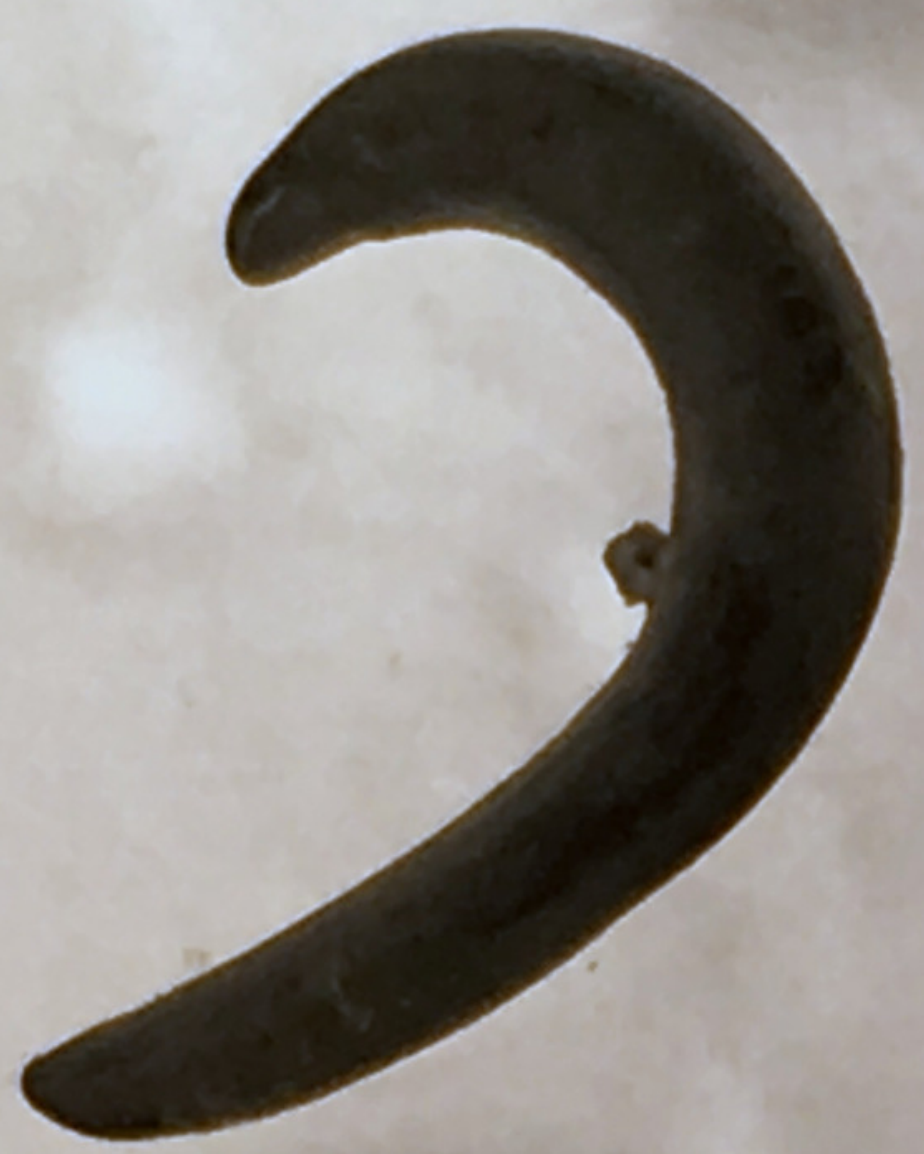




\section{Figure 21}

Diversibipalium sp. 'black' from Metropolitan France, preserved specimen.

Specimen MNHN JL090. Ventral aspect. The ventral ground colour is grey, with the creeping sole a lighter tone. The pharynx is slightly protruded from the mouth, and the gonopore is evident as a small transverse white slit on the creeping sole some $2 \mathrm{~mm}$ below to the mouth. Scale is in $\mathrm{mm}$. Photo by Jean-Lou Justine. 


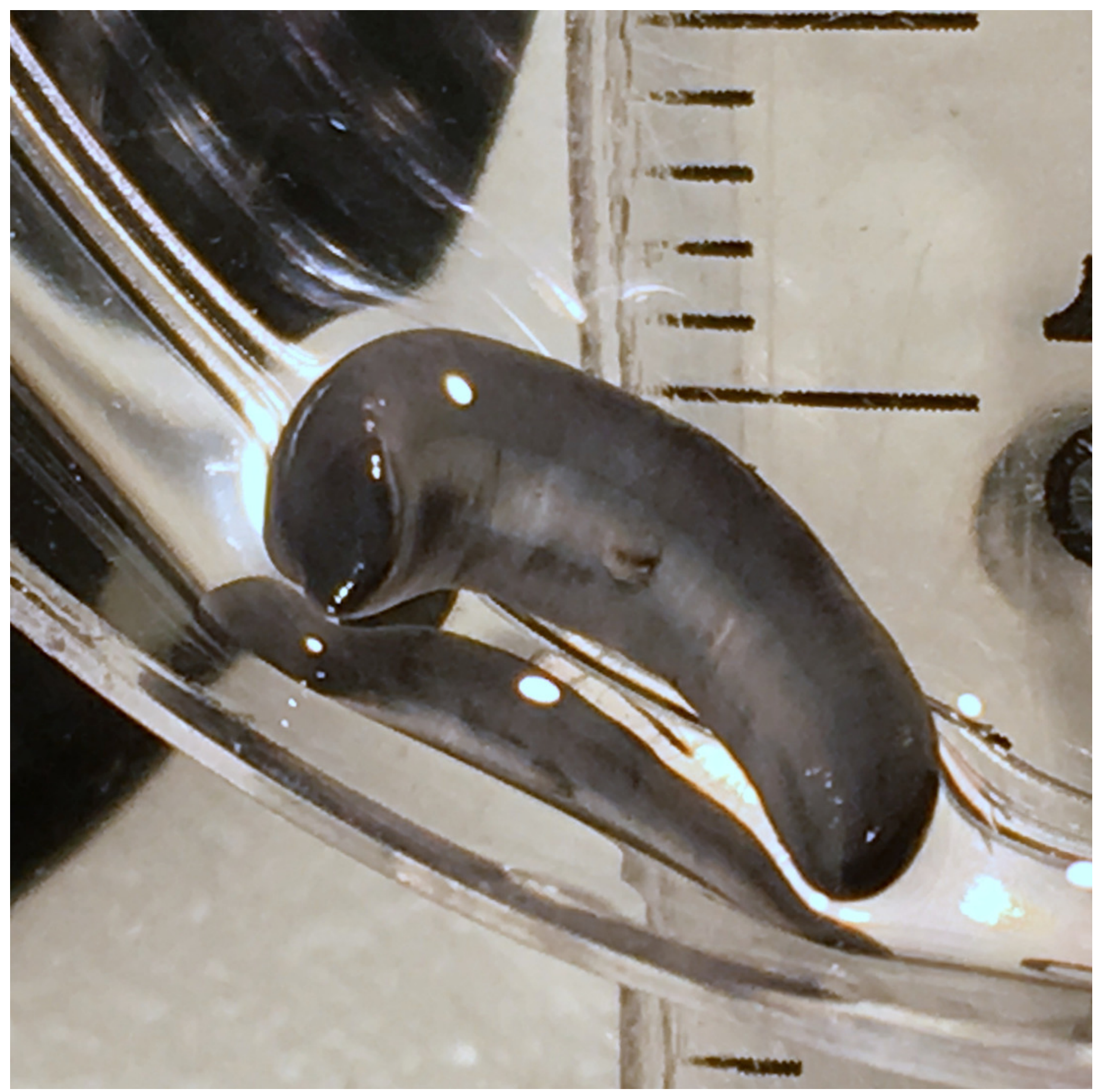




\section{Figure 22}

Diversibipalium sp. 'blue' from Mayotte, Indian Ocean, dorsal aspect.

The headplate of this small planarian is a brown colour, with a blue dorsum. This living specimen is approximately $45 \mathrm{~mm}$ long. Photo by Benoît Duperron.

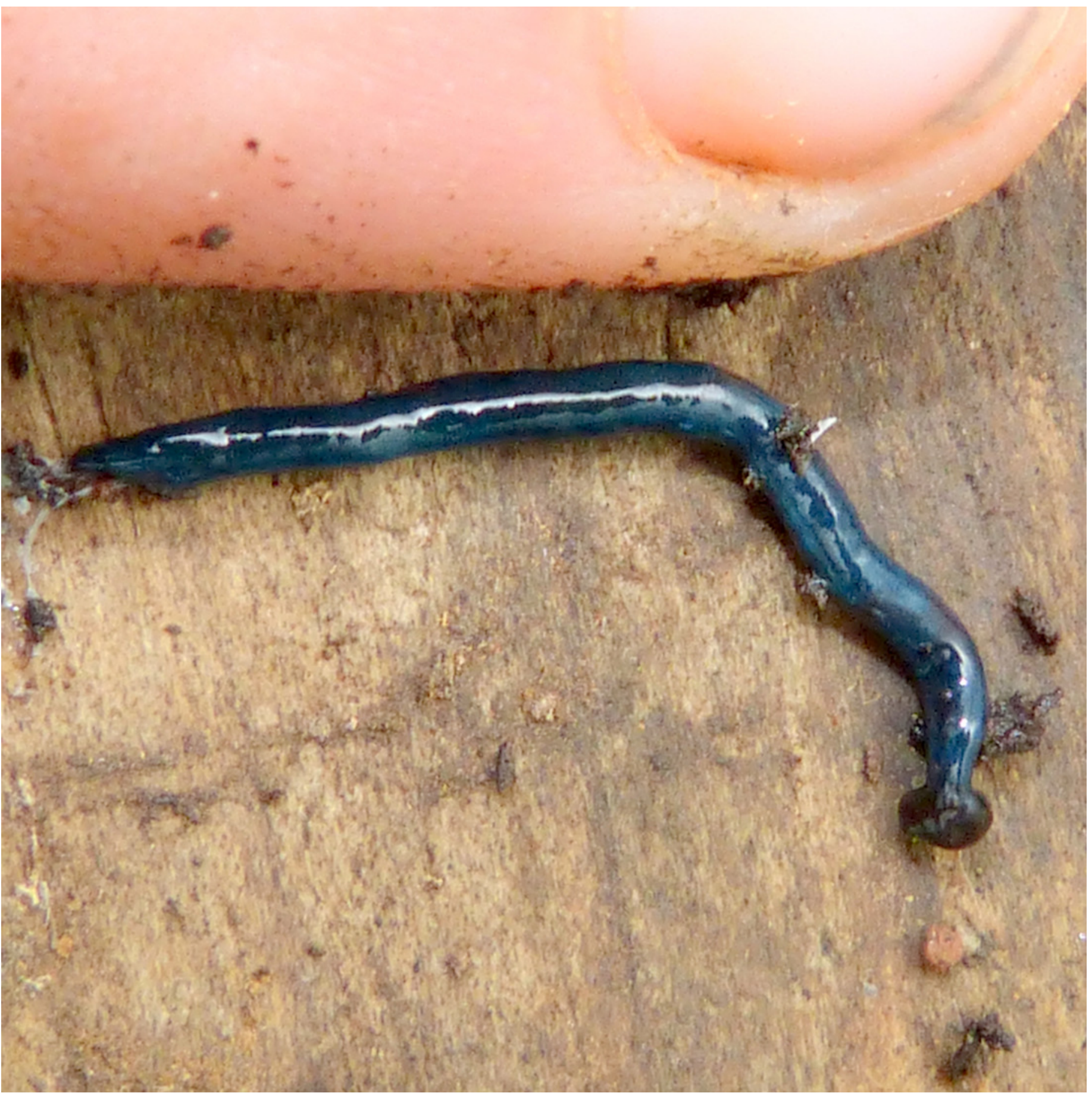




\section{Figure 23}

Diversibipalium sp. 'blue' from Mayotte, Indian Ocean, dorsal aspect.

Specimen MNHN JL282. The headplate of this small planarian is a rusty-brown colour that extends to some irregular patches on the "neck". The dorsal ground colour is an iridescent blue-green ("dark turquoise glitter"). Photo by Laurent Charles.

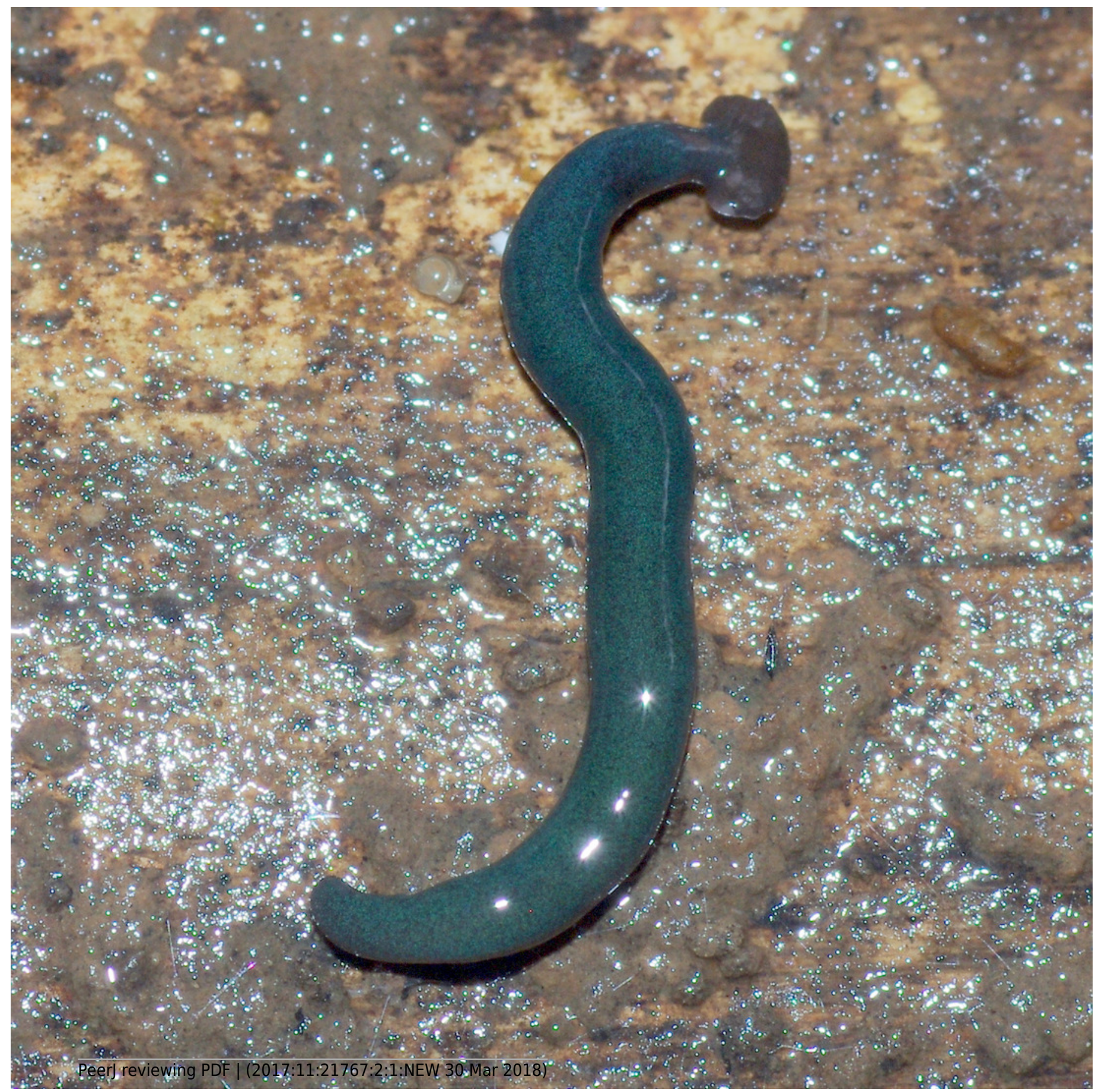




\section{Figure 24}

Diversibipalium sp. 'blue' from Mayotte, Indian Ocean, dorsal aspect.

Specimen MNHN JL282. As for Figure 25. Photo by Laurent Charles.

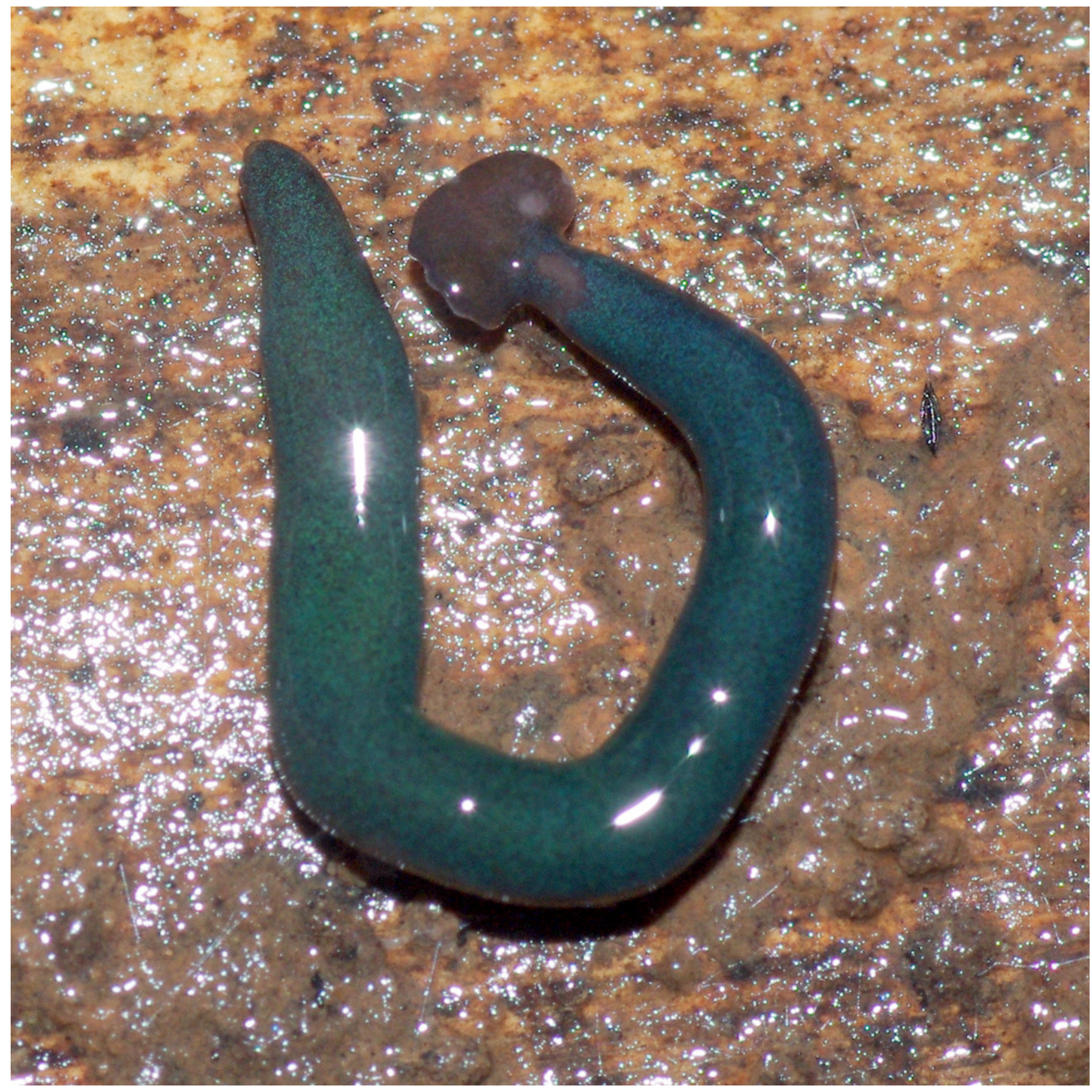




\section{Figure 25}

Diversibipalium sp. 'blue' from Mayotte, Indian Ocean. Dorsal aspect of a regenerating specimen with a damaged anterior end.

Specimen MNHN JL280. Under appropriate lighting, the colour of the specimen takes on a beautiful, almost metallic green colour. The iridescence and blue-green colour are lost on fixation, leaving the specimen a dark brown. Photo by Laurent Charles. 


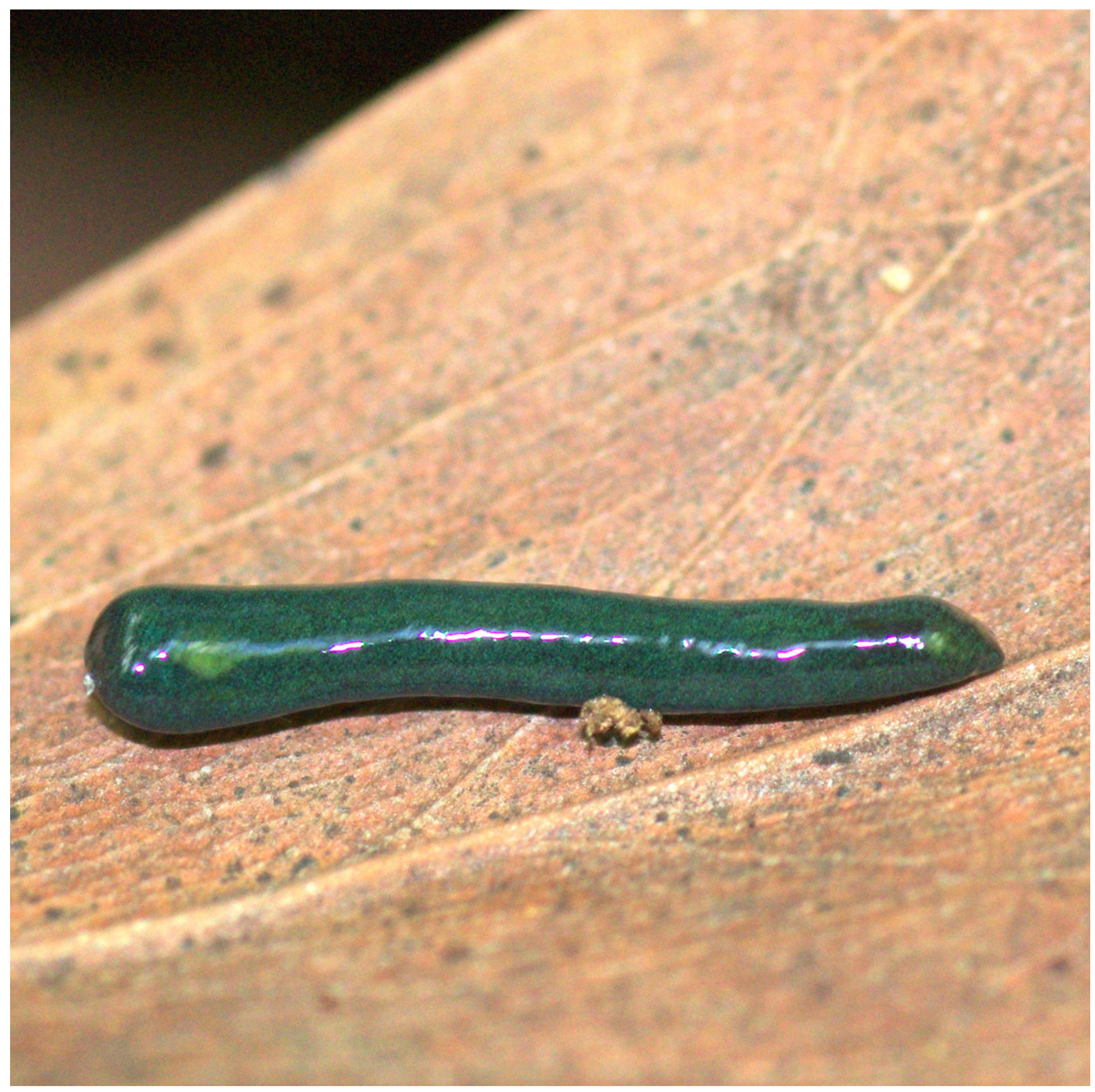




\section{Figure 26}

Diversibipalium sp. 'blue' from Mayotte, Indian Ocean. Dorsal aspect of a regenerating specimen with a damaged anterior end.

Specimen MNHN JL280. A small portion of the brown-pigmented ventral surface with the median pale creeping sole, can be seen. Photo by Laurent Charles. 


\section{Figure 27}

Map of the south-eastern part of France, showing numerous new Bipaliine records.

Names of communes are indicated. Most records are from the Department of PyrénéesAtlantiques, especially its lower part near the Atlantic Ocean.

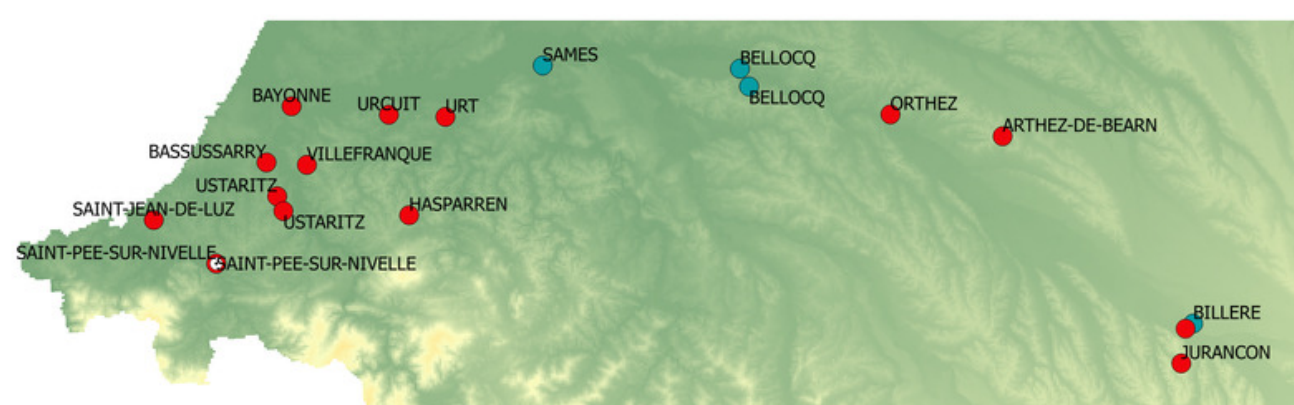

\section{Outdoors}

- Bipalium kewense

- Diversibipalium multilineatum

- Diversibipalium sp."black"

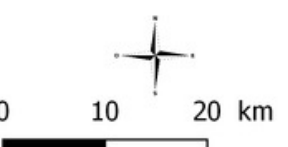

$20 \mathrm{~km}$ 
Figure 28

Map of the World, showing new records of bipaliine flatworms from French territories.

New records are from four continents (North America, South America, Polynesia, Africa).

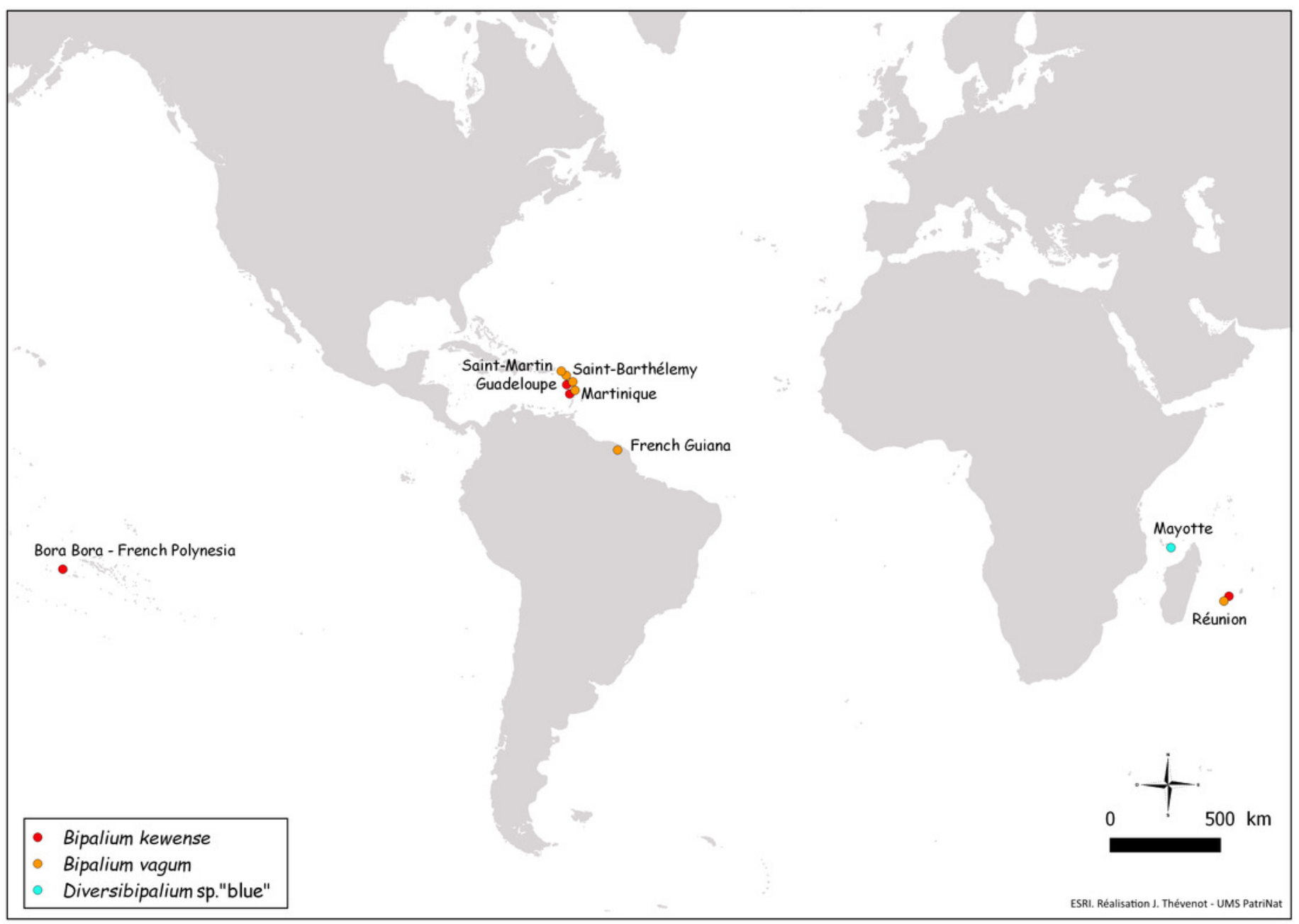




\section{Table $\mathbf{1}$ (on next page)}

Invasive land planarians found in Europe, authors of taxa and key references.

This table provides complete information about authors and taxa and combination, thus making the general text lighter. Sluys (2016) listed additional species with limited records and information: Artioposthia exulans Dendy, 1901, Australoplana sanguinea (Moseley, 1877), Dolichoplana striata Moseley, 1877, Kontikia andersoni Jones, 1981. 


\begin{tabular}{|c|c|c|c|}
\hline Taxon and authors & Synonyms & References for taxon & $\begin{array}{l}\text { Main references for presence in } \\
\text { Europe }\end{array}$ \\
\hline $\begin{array}{l}\text { Arthurdendyus triangulatus (Dendy, 1896) } \\
\text { Jones, } 1999\end{array}$ & $\begin{array}{l}\text { Artioposthia } \\
\text { triangulata }\end{array}$ & Dendy 1895, Jones 1999 & Boag et al. 1994 \\
\hline $\begin{array}{l}\text { Platydemus manokwari De Beauchamp, } \\
1963\end{array}$ & & de Beauchamp 1962 & Justine et al. 2014b \\
\hline $\begin{array}{l}\text { Obama nungara Carbayo, Álvarez-Presas, } \\
\text { Jones \& Riutort, } 2016\end{array}$ & Obama marmorata & Carbayo et al. 2016 & Carbayo et al. 2016 \\
\hline Parakontikia ventrolineata (Dendy, 1892) & Kontikia & Dendy 1891, Winsor 1991 & Álvarez-Presas et al. 2014 \\
\hline Winsor, 1991 & ventrolineata & & \\
\hline Caenoplana coerulea Moseley, 1877 & & Moseley 1877 & $\begin{array}{l}\text { Álvarez-Presas et al. 2014, } \\
\text { Breugelmans et al. } 2012\end{array}$ \\
\hline $\begin{array}{l}\text { Caenoplana bicolor (Graff, 1899) Winsor, } \\
1991\end{array}$ & Geoplana bicolor & von Graff 1899, Winsor 1991 & Álvarez-Presas et al. 2014 \\
\hline Marionfyfea adventor Jones \& Sluys, 2016 & & Jones \& Sluys 2016 & Jones \& Sluys 2016 \\
\hline $\begin{array}{l}\text { Diversibipalium multilineatum (Makino \& } \\
\text { Shirasawa, 1983) Kubota \& Kawakatsu, } \\
2010\end{array}$ & $\begin{array}{l}\text { Bipalium } \\
\text { multilineatum }\end{array}$ & $\begin{array}{l}\text { Makino \& Shirasawa 1983, } \\
\text { Kubota \& Kawakatsu } 2010\end{array}$ & Mazza et al. 2016, This paper \\
\hline Bipalium kewense Moseley, 1878 & & Moseley 1878 & This paper \\
\hline
\end{tabular}




\section{Table 2 (on next page)}

Specimens of bipaliines with molecular identification.

* JL177 already published (Mazza et al. 2016); ** specimen from hot house, all others are from the open; *** Specimen MCSN 719.990/77.590 kept in Museo Cantonale di Storia Naturale, Lugano, Switzerland, forwarded by Jean Mariaux (Geneva, Switzerland). BK: Bipalium kewense; BV: Bipalium vagum; DM:

Diversibipalium multilineatum; Dblue: Diversibipalium sp. 'blue'; Dblack: Diversibipalium sp. 'black'.

Most collectors were citizens; these collectors are professional: Arnaud Bellina, FREDON Bourgogne; Laurent Charles, Muséum Science et Nature, Bordeaux; Mathieu Coulis, CIRAD Martinique; Pierre-Damien Lucas, FREDON Martinique; Guy Van Laere, Parc National de Guadeloupe. 


\begin{tabular}{|c|c|c|c|c|c|c|c|c|c|}
\hline Species & MNHN & GenBank \# & date & Locality & Department / State & Country - Continent & $\mathrm{COI}$ & Replicates & Collector \\
\hline BK & JL089 & MG655587 & $12 / 11 / 2013$ & Saint Pée sur Nivelle & Pyrénées-Atlantiques & Met. France - Europe & short & 1 & Consent not obtained \\
\hline BK & JL160 & MG655605 & $23 / 05 / 2014$ & Cannes & Alpes-Maritimes & Met. France - Europe & short & 1 & lachia, Valeria \\
\hline BK & JL167 & MG655615 & $24 / 08 / 2014$ & Orthez & Pyrénées-Atlantiques & Met. France - Europe & short & 1 & Rougeux, Christian \\
\hline BK & JL174 & MG655616 & 03/09/2014 & Bassussary & Pyrénées-Atlantiques & Met. France - Europe & long & 1 & Mercader, Elisabeth \\
\hline BK & JL176 ** & MG655617 & $05 / 09 / 2014$ & Auxerre (hothouse) & Yonne & Met. France - Europe & long & 1 & Bellina, Arnaud \\
\hline BK & JL184 & MG655603 & Oct. 2014 & Ustaritz & Pyrénées-Atlantiques & Met. France - Europe & short & 1 & Goyheneche, Iker \\
\hline BK & JL188 & MG655604 & $08 / 10 / 2014$ & Miramar & Grande Porto & Portugal - Europe & short & 1 & Soarès, Luciana \\
\hline BK & $\mathrm{JL} 212$ & MG655592 & $19 / 12 / 2014$ & Mimbastes & Landes & Met. France - Europe & long & 1 & Jouveau, Séverin \\
\hline BK & JL224 & MG655607 & $23 / 02 / 2015$ & Trois Rivières & Guadeloupe & Guadeloupe - C. America & long & 1 & Van Laere, Guy \\
\hline BK & JL233 & MG655608 & $27 / 09 / 2014$ & Monaco & Monaco & Monaco - Europe & long & 3 & Dusoulier, François \\
\hline BK & JL253 & MG655609 & $21 / 03 / 2015$ & Trois Rivières & Guadeloupe & Guadeloupe - C. America & short & 1 & Van Laere, Guy \\
\hline BK & $J L 254$ & MG655610 & $15 / 05 / 2015$ & Matoury & French Guiana & French Guiana - S. America & short & 2 & Girault, Rémi \\
\hline BK & JL270 & MG655594 & $23 / 04 / 2015$ & Ducos & Martinique & Martinique - C. America & long & 1 & Lucas, Pierre-Damien \\
\hline BK & JL308 & MG655602 & 08/09/2016 & Morne Vert & Guadeloupe & Guadeloupe - C. America & short & 1 & Coulis, Mathieu \\
\hline BV & JL073 & MG655611 & Aug. 2013 & Sanibel & Florida & USA - North America & short & 1 & Justine, Jean-Lou \\
\hline BV & JL163 & MG655613 & July 2014 & Sanibel & Florida & USA - North America & short & 1 & Justine, Jean-Lou \\
\hline BV & JL164 & MG655614 & July 2014 & Sanibel & Florida & USA - North America & short & 1 & Justine, Jean-Lou \\
\hline BV & JL213 & MG655593 & $29 / 11 / 2014$ & Anse-Bertrand & Guadeloupe & Guadeloupe - C. America & long & 1 & Charles, Laurent \\
\hline BV & JL268 & MG655595 & Dec. 2014 & Montserrat & Montserrat & Montserrat - C. America & short & 1 & Shoobs, Nathaniel F. \\
\hline BV & JL307 & MG655601 & $19 / 11 / 2015$ & Morne Vert & Guadeloupe & Guadeloupe - C. America & short & 1 & Coulis, Mathieu \\
\hline DM & JL177 * & KT922162 & $30 / 09 / 2014$ & Léguevin & Haute-Garonne & Met. France - Europe & long & 1 & Chaim, Florence \\
\hline DM & JL059 & MG655618 & $15 / 06 / 2013$ & La Bastide de Serou & Ariège & Met. France - Europe & short & 1 & Brugnara, Sébastien \\
\hline DM & JL142 & MG655612 & $22 / 04 / 2014$ & Saubrigues & Landes & Met. France - Europe & long & 2 & Robineau, Thiérry \\
\hline DM & JL161 & MG655606 & $11 / 06 / 2015$ & Bellocq & Pyrénées-Atlantiques & Met. France - Europe & long & 1 & Audiot, Marie-Claude \\
\hline DM & JL208 & MG655589 & $11 / 06 / 2014$ & Bellocq & Pyrénées-Atlantiques & Met. France - Europe & long & 1 & Audiot, Marie-Claude \\
\hline DM & JL209 & MG655590 & $12 / 06 / 2014$ & Bellocq & Pyrénées-Atlantiques & Met. France - Europe & long & 1 & Audiot, Marie-Claude \\
\hline DM & JL210 & MG655591 & June 2014 & Bellocq & Pyrénées-Atlantiques & Met. France - Europe & long & 1 & Audiot, Marie-Claude \\
\hline DM & JL298 *** & MG655600 & $01 / 06 / 2016$ & Novazzano & Ticino Canton & Switzerland - Europe & long & 1 & Pollini, Lucia \\
\hline DBlue & $\mathrm{JL} 280$ & MG655596 & 2015 & Mtsamboro & Mayotte & Mayotte - Africa & long & 1 & Charles, Laurent \\
\hline DBlue & JL281 & MG655597 & $29 / 04 / 2015$ & Mtsamboro & Mayotte & Mayotte - Africa & long & 3 & Charles, Laurent \\
\hline DBlue & JL282 & MG655598 & $30 / 04 / 2015$ & Ouangani & Mayotte & Mayotte - Africa & long & 1 & Charles, Laurent \\
\hline DBlue & JL284 & MG655599 & $05 / 05 / 2015$ & Mtsamboro & Mayotte & Mayotte - Africa & long & 1 & Charles, Laurent \\
\hline DBlack & JL090 & MG655588 & $12 / 11 / 2013$ & Saint Pée sur Nivelle & Pyrénées-Atlantiques & Met. France - Europe & short & 1 & Consent not obtained \\
\hline
\end{tabular}

1 


\section{Table 3(on next page)}

Divergences between "short" sequences of bipaliine flatworms.

There was a total of 266 positions in the final dataset. 


\begin{tabular}{lllllll}
\hline & kewense & multilineatum & nobile & “black" & "blue" & vagum \\
\hline multilineatum & 0.109 & & & & & \\
nobile & 0.131 & 0.131 & & & & \\
"black" & 0.149 & 0.164 & 0.163 & & & \\
“blue" & 0.206 & 0.202 & 0.164 & 0.192 & & \\
vagum & 0.140 & 0.168 & 0.163 & 0.140 & 0.159 & \\
adventium & 0.136 & 0.178 & 0.173 & 0.173 & 0.212 & 0.164 \\
\hline
\end{tabular}




\section{Table 4 (on next page)}

Divergences between "Iong" sequences of bipaliine flatworms.

There was a total of 857 positions in the final dataset. 


\begin{tabular}{llll}
\hline & kewense & multilineatum & "blue" \\
\hline multilineatum & 0.159 & & \\
"blue" & 0.230 & 0.259 & \\
vagum & 0.167 & 0.179 & 0.223 \\
\hline
\end{tabular}

1 


\section{Table 5 (on next page)}

Records of Bipalium kewense identified from photographs.

Photographs were obtained through citizen science; specimens were identified from photographs by the authors. No molecular identification was possible. There were 36 records ( 35 from outdoor and one from a hothouse). The name of the authors of photographs are indicated only when a formal consent to publish was obtained from the authors. Photographs are in Supplement 2. For the first record, see also Gerlach (2017).

* Muséum d'Histoire Naturelle, Nice, France; ** FREDON île de France. 


\begin{tabular}{|c|c|c|c|c|c|}
\hline$\#$ & Date & Locality & Department / State & Country - Continent & Origin of data \\
\hline K01 & $20 / 08 / 2017$ & Bora Bora & French Polynesia & French Polynesia - Oceania & Gerlach, Justin \\
\hline K02 & $13 / 10 / 2010$ & Basse-Terre & Guadeloupe & Guadeloupe - C. America & Guezennec, Pierre et Claudine \\
\hline K03 & $22 / 01 / 2014$ & Unknown & Guadeloupe & Guadeloupe - C. America & Consent not obtained \\
\hline К04 & $14 / 01 / 2007$ & Petit-Bourg & Guadeloupe & Guadeloupe - C. America & Lurel, Félix \\
\hline K05 & $19 / 02 / 2015$ & La Trinité & Martinique & Martinique - C. America & Delannoye, Régis \\
\hline K06 & $19 / 04 / 2016$ & Saint Joseph & Martinique & Martinique - C. America & Andrebe, Silvio \\
\hline K07 & $25 / 08 / 2017$ & Plaine des Cafres & La Réunion & La Réunion - Africa & Pronier, Pascal \\
\hline K08 & $03 / 11 / 2013$ & Cagnes-sur-Mer & Alpes-Maritimes & Met. France - Europe & Gros, Pierre \\
\hline K09 & $19 / 01 / 2014$ & Cagnes-sur-Mer & Alpes-Maritimes & Met. France - Europe & Gros, Pierre \\
\hline K10 & $05 / 11 / 2014$ & Cagnes-sur-Mer & Alpes-Maritimes & Met. France - Europe & Gros, Pierre \\
\hline K11 & $16 / 10 / 2013$ & Beaulieu-sur-Mer & Alpes-Maritimes & Met. France - Europe & Pelcer, Jean-Paul \\
\hline K12 & $21 / 07 / 2014$ & Nice & Alpes-Maritimes & Met. France - Europe & Gerriet, Olivier * \\
\hline K13 & $15 / 10 / 2014$ & Appietto & Corse-Sud (Corsica) & Met. France - Europe & Consent not obtained \\
\hline K14 & $17 / 10 / 2013$ & Pietrosella & Corse-Sud (Corsica) & Met. France - Europe & Senee, Patrick \\
\hline K15 & $23 / 08 / 2014$ & Arcachon & Gironde & Met. France - Europe & Consent not obtained \\
\hline K16 & $21 / 11 / 2002$ & Saint-Jean-de-Vedas & Hérault & Met. France - Europe & Peaucellier, Gérard \\
\hline K17 & $27 / 10 / 2014$ & Biscarosse & Landes & Met. France - Europe & Consent not obtained \\
\hline K18 & $27 / 09 / 2008$ & Hagetmau & Landes & Met. France - Europe & Jeannotin, Josette \\
\hline K19 & $22 / 09 / 2016$ & Nantes & Loire-Atlantique & Met. France - Europe & Consent not obtained \\
\hline K20 & $16 / 10 / 2014$ & Grimaud & Var & Met. France - Europe & Bernez, Alain \\
\hline K21 & $01 / 08 / 2014$ & Toulon & Var & Met. France - Europe & Consent not obtained \\
\hline K22 & $29 / 07 / 2014$ & Sens (Hothouse) & Yonne & Met. France - Europe & Burel, Jonathan ** \\
\hline K23 & $23 / 10 / 2017$ & Peyrouse & Hautes-Pyrénées & Met. France - Europe & Tremosa, Clémence \\
\hline K24 & $17 / 12 / 2014$ & Arthez de Béarn & Pyrénées-Atlantiques & Met. France - Europe & Sillard, Dominique \\
\hline K25 & $17 / 09 / 2017$ & Billère & Pyrénées-Atlantiques & Met. France - Europe & Rolland, Geneviève \\
\hline K26 & $28 / 01 / 2018$ & Billère & Pyrénées-Atlantiques & Met. France - Europe & Rolland, Geneviève \\
\hline K27 & $20 / 09 / 2014$ & Bayonne & Pyrénées-Atlantiques & Met. France - Europe & Bonnefous, François \\
\hline K28 & $18 / 08 / 2014$ & Hasparren & Pyrénées-Atlantiques & Met. France - Europe & Voise, Mireille \\
\hline K29 & $22 / 04 / 2016$ & Jurançon (near) & Pyrénées-Atlantiques & Met. France - Europe & Pauchet, Marjolaine \\
\hline K30 & 29/04/2016 & Nay & Pyrénées-Atlantiques & Met. France - Europe & Lamaille, Corinne \\
\hline
\end{tabular}




\begin{tabular}{llllll} 
K31 & $28 / 09 / 2014$ & Orthez & Pyrénées-Atlantiques & Met. France - Europe & Rougeux, Christian \\
K32 & $22 / 08 / 2016$ & Saint Jean de Luz & Pyrénées-Atlantiques & Met. France - Europe & Centelles, Ruben \\
K33 & $01 / 01 / 1999$ & Urcuit & Pyrénées-Atlantiques & Met. France - Europe & Esposito, Mario \\
K34 & $14 / 09 / 2014$ & Urt & Pyrénées-Atlantiques & Met. France - Europe & Chanderot, Vincent \\
K35 & $12 / 08 / 2017$ & Ustaritz & Pyrénées-Atlantiques & Met. France - Europe & Lescourret, Monique \& Bernard \\
K36 & $14 / 09 / 2014$ & Villefranque & Pyrénées-Atlantiques & Met. France - Europe & Consent not obtained \\
\hline
\end{tabular}




\section{Table 6(on next page)}

Records of Diversibipalium multilineatum identified from photographs.

Photographs were obtained through citizen science; specimens were identified from photographs by the authors. No molecular identification was possible. There were 11 records, including 2 from hothouses. The name of the authors of photographs are indicated only when a formal consent to publish was obtained from the authors. Photographs are in Supplement 2.

* FREDON Île de France. 


\begin{tabular}{llllll}
\hline$\#$ & Date & Locality & Department / State & Country - Continent & Origin \\
\hline M01 & $27 / 06 / 2010$ & Longages & Haute-Garonne & Met. France - Europe & Lombard, Yoann \\
M02 & $22 / 03 / 2011$ & Longages & Haute-Garonne & Met. France - Europe & Lombard, Yoann \\
M03 & $06 / 07 / 2016$ & Saint-Egrève & Isère & Met. France - Europe & Tuaillon, Jean-Louis \\
M04 & $17 / 05 / 2017$ & Saint-Egrève & Isère & Met. France - Europe & Tuaillon, Jean-Louis \\
M05 & $27 / 06 / 2016$ & Benquet & Landes & Met. France - Europe & Broustaut, François \\
M06 & $28 / 03 / 2014$ & Cahors (Hothouse) & Lot & Met. France - Europe & Consent not obtained \\
M07 & $04 / 07 / 2014$ & Andilly (Hothouse) & Val d'Oise & Met. France - Europe & Burel, Jonathan * \\
M08 & $27 / 04 / 2015$ & Magny-en-Vexin & Val d'Oise & Met. France - Europe & Mellac, Céline \\
M09 & $29 / 05 / 2016$ & Magny-en-Vexin & Val d'Oise & Met. France - Europe & Mellac, Céline \\
M10 & $19 / 04 / 2010$ & Sames & Pyrénées-Atlantiques & Met. France - Europe & Grenier-Falaise, Nadine \\
M11 & $07 / 04 / 2017$ & Billère & Pyrénées-Atlantiques & Met. France - Europe & Vincent, Jean-François \\
\hline
\end{tabular}




\section{Table 7 (on next page)}

Records of Bipalium vagum identified from photographs (no molecular identification).

Photographs were obtained through citizen science; specimens were identified from photographs by the authors. No molecular identification was possible. There were 33 records, all from outdoor. The name of the authors of photographs are indicated only when a formal consent to publish was obtained from the authors. Photographs are in Supplement 2. 


\begin{tabular}{|c|c|c|c|c|c|}
\hline$\#$ & Date & Locality & Department / State & Country - Continent & Origin \\
\hline V01 & $21 / 06 / 2005$ & Cayenne & French Guiana & French Guiana - S. America & Girault, Rémi \\
\hline V02 & $15 / 05 / 2017$ & Macouria & French Guiana & French Guiana - S. America & Boutin, Élodie \\
\hline V03 & $12 / 05 / 2017$ & Saint-Laurent-du-Maroni & French Guiana & French Guiana - S. America & Muraine, François Xavier \\
\hline V04 & 26/07/2017 & Saül & French Guiana & French Guiana - S. America & Sant, Sébastien \\
\hline V05 & 21/08/2017 & Petit-Bourg & Guadeloupe & French Guiana - S. America & De Tienda, Marine \\
\hline V06 & $24 / 11 / 2013$ & Gosier & Guadeloupe & Guadeloupe - C. America & Consent not obtained \\
\hline V07 & $30 / 10 / 2016$ & Gosier & Guadeloupe & Guadeloupe - C. America & Brisson, Bernard \\
\hline V08 & $22 / 11 / 2013$ & Petit Bourg & Guadeloupe & Guadeloupe - C. America & Oettly, Olivier \\
\hline V09 & $22 / 11 / 2014$ & Petit Bourg & Guadeloupe & Guadeloupe - C. America & Marques, Maryvonne \\
\hline V10 & 29/04/2011 & Petit-Bourg & Guadeloupe & Guadeloupe - C. America & Guezennec, Pierre et Claudine \\
\hline V11 & $21 / 10 / 2017$ & Petit-Canal & Guadeloupe & Guadeloupe - C. America & Charles, Laurent \\
\hline V12 & $29 / 11 / 2016$ & Le Moule & Guadeloupe & Guadeloupe - C. America & Consent non obtained \\
\hline V13 & $25 / 07 / 2010$ & La Trinité & Martinique & Martinique - C. America & Delannoye, Régis \\
\hline V14 & $18 / 11 / 2015$ & Morne Vert & Martinique & Martinique - C. America & Coulis, Mathieu \\
\hline V15 & 05/01/2018 & Trois Ilets & Martinique & Martinique - C. America & Consent non obtained \\
\hline V16 & $01 / 04 / 2014$ & Saint Barthélemy & Saint Barthélemy & Saint Barthélemy - C. America & Moulard, Grégory \\
\hline V17 & 01/05/2014 & Saint Barthélemy & Saint Barthélemy & Saint Barthélemy - C. America & Consent not obtained \\
\hline V18 & $11 / 05 / 2014$ & Saint Martin & Saint Martin & Saint Martin - C. America & Yokoyama, Mark \\
\hline V19 & $21 / 11 / 2015$ & Avirons & La Réunion & La Réunion - Africa & Consent not obtained \\
\hline V20 & $23 / 03 / 2017$ & Bras Panon & La Réunion & La Réunion - Africa & Saman-Latchimy, Teddy \\
\hline V21 & $29 / 03 / 2017$ & Le Tampon & La Réunion & La Réunion - Africa & Consent not obtained \\
\hline V22 & $26 / 10 / 2014$ & Petite Ile & La Réunion & La Réunion - Africa & Abonnenc, José \\
\hline V23 & $12 / 03 / 2016$ & Petite lle & La Réunion & La Réunion - Africa & Le Gars, René \\
\hline V24 & $16 / 05 / 2014$ & Saint Louis & La Réunion & La Réunion - Africa & Faujour, Anne \\
\hline V25 & $08 / 04 / 2014$ & Saint Paul & La Réunion & La Réunion - Africa & Consent not obtained \\
\hline V26 & $16 / 03 / 2016$ & Saint Pierre & La Réunion & La Réunion - Africa & Collet, Jean \\
\hline V27 & $10 / 03 / 2013$ & Sainte Marie & La Réunion & La Réunion - Africa & Fontaine, Romuald \\
\hline V28 & 06/03/2016 & Sainte Marie & La Réunion & La Réunion - Africa & Fontaine, Romuald \\
\hline V29 & $12 / 02 / 2009$ & unknown & La Réunion & La Réunion - Africa & Gilson, Michel \\
\hline V30 & 03/03/2010 & unknown & La Réunion & La Réunion - Africa & Gilson, Michel \\
\hline V31 & $01 / 05 / 2011$ & unknown & La Réunion & La Réunion - Africa & Martiré, Dominique \\
\hline V32 & $28 / 10 / 2013$ & unknown & La Réunion & La Réunion - Africa & Martiré, Dominique \\
\hline V33 & $17 / 08 / 2015$ & unknown & La Réunion & La Réunion - Africa & Lacoste, Marie \\
\hline
\end{tabular}




\section{Table 8 (on next page)}

Records of Diversibipalium "blue" identified from photographs (no molecular identification).

1 record. 


\begin{tabular}{|c|c|c|c|c|}
\hline Date & Locality & Department / State & Country - Continent & Origin \\
\hline $07 / 03 / 2014$ & unknown & Mayotte & Mayotte - Africa & Duperron, Benoît \\
\hline
\end{tabular}


Table 9 (on next page)

Measurements of living specimens of bipaliines.

Measurements were estimated from photographs with scales obtained from citizen science (Supplemental Files $1 \& 2$ ). 


\begin{tabular}{|c|c|c|c|}
\hline Species & $\begin{array}{l}\text { MNHN Specimen } \\
\text { or photograph } \\
\text { from Citizen } \\
\text { Science }\end{array}$ & Locality & $\begin{array}{l}\text { Body length } \\
\text { (cm) }\end{array}$ \\
\hline \multirow[t]{12}{*}{ Bipalium kewense } & MNHN JL089 & France & 21 \\
\hline & MNHN JL184 & France & 16 \\
\hline & MNHN JL188 & Portugal & 25 \\
\hline & MNHN JL224 & Guadeloupe & 21 \\
\hline & MNHN JL270 & Martinique & 11 \\
\hline & K04 & Guadeloupe & 13 \\
\hline & K05 & Martinique & 20 \\
\hline & K07 & La Réunion & 10 \\
\hline & K24 & France & 20 \\
\hline & $\mathrm{K} 25$ & France & 27 \\
\hline & $\mathrm{K} 28$ & France & 15 \\
\hline & K35 & France & 17 \\
\hline \multirow[t]{2}{*}{ Diversibipalium multilineatum } & MNHN JL177 & France & 15 \\
\hline & MNHN JL059 & France & 21 \\
\hline Bipalium vagum & V04 & French Guiana & 3.6 \\
\hline
\end{tabular}

